\title{
Signal Incongruence and Its Consequences A Study of Media Disapproval and CEO Overcompensation
}

\author{
Vergne, Jean-Philippe; Wernicke, Georg; Brenner, Steffen
}

Document Version

Accepted author manuscript

Published in:

Organization Science

DOI:

10.1287/orsc.2018.1209

Publication date:

2018

License

Unspecified

Citation for published version (APA):

Vergne, J-P., Wernicke, G., \& Brenner, S. (2018). Signal Incongruence and Its Consequences: A Study of Media Disapproval and CEO Overcompensation. Organization Science, 29(5), 796-817.

https://doi.org/10.1287/orsc.2018.1209

Link to publication in CBS Research Portal

\section{General rights}

Copyright and moral rights for the publications made accessible in the public portal are retained by the authors and/or other copyright owners and it is a condition of accessing publications that users recognise and abide by the legal requirements associated with these rights.

Take down policy

If you believe that this document breaches copyright please contact us (research.lib@cbs.dk) providing details, and we will remove access to the work immediately and investigate your claim. 


\title{
Signal Incongruence and Its Consequences: A Study of Media Disapproval and CEO Overcompensation
}

\author{
Jean-Phillipe Vergne, Georg Wernicke, and Steffen Brenner
}

Journal article (Accepted manuscript*)

\section{Please cite this article as:}

Vergne, J-P., Wernicke, G., \& Brenner, S. (2018). Signal Incongruence and Its Consequences: A Study of Media Disapproval and CEO Overcompensation. Organization Science, 295), 796-817.

DOI: 10.1287/orsc.2018.1209

DOI: 10.1287/orsc.2018.1209

* This version of the article has been accepted for publication and undergone full peer review but has not been through the copyediting, typesetting, pagination and proofreading process, which may lead to differences between this version and the publisher's final version AKA Version of Record.

Uploaded to CBS Research Portal: February 2019 


\title{
SIGNAL INCONGRUENCE AND ITS CONSEQUENCES:
}

\section{A STUDY OF MEDIA DISAPPROVAL AND CEO OVERCOMPENSATION}

\author{
JP Vergne (jvergne@,ivey.ca) \\ Ivey Business School, 1255 Western Rd, N6G 0N1 London ON, Canada \\ Georg Wernicke (wernicke@hec.fr) \\ HEC Paris, 1 rue de la Liberation, 78350 Jouy-en-Josas, France \\ Steffen Brenner (sbr.int@.cbs.dk) \\ Copenhagen Business School, Porcelaenshaven 24, 2000 Frederiksberg, Denmark
}

\begin{abstract}
We draw on the signaling and infomediary literatures to examine how media evaluations of CEO overcompensation (a negative cue associated with selfishness and greed) are affected by the presence of corporate philanthropy (a positive cue associated with altruism and generosity). In line with our theory on signal incongruence, we find that firms engaged in philanthropy receive more media disapproval when they overcompensate their CEO, but they are also more likely to decrease CEO overcompensation as a response. Our study contributes to the signaling literature by theorizing about signal incongruence, and to infomediary and corporate governance research by showing that media disapproval can lead to lower executive compensation. We also reconcile two conflicting views on firm prosocial behavior by showing that, in the presence of incongruent cues, philanthropy can simultaneously enhance and damage media evaluations of firms and CEOs. Taken together, these findings shed new light on the media as agents of external corporate governance for firms and open new avenues for research on executive compensation.
\end{abstract}

Keywords: media, CEO compensation, social evaluations, philanthropy, signaling

\footnotetext{
Authors' note/Acknowledgments: We are very grateful for the insightful guidance provided by Senior Editor Ruth V. Aguilera throughout the revision process, and for the feedback given by three anonymous reviewers. We thank Carlo Parlato for his assistance with data collection, and Alexander Hahn, Martin Artz and Torsten Biemann for feedback on earlier versions. This paper has benefited from input received at HEC Paris, IE Business School, Erasmus University, INSEAD, Tilburg University, Warwick, WHU-Beisheim School of Management, Frankfurt School of Finance and Management, Free University Berlin, and the Universities of Passau, Lugano, Cologne and Mannheim. Feedback received at AoM Vancouver, SMS Denver, EURAM Warsaw, ICGS Copenhagen, ISC Jerusalem, and ARCS Chicago was also helpful. While the authors did not feel overcompensated for working on this study, without a 2SLS regression it is impossible to know for sure.
} 
"NOTHING in business excites so much interest in the wider world as the pay of top executives".

-The Economist, October 9, 2003

\section{INTRODUCTION}

Capitalist democracies operate with a decentralized information system whereby the media convey information about firms to stakeholders and openly echo concerns about issues. In this context, firms face pressure from the media, which frequently disapprove of firms perceived to violate societal norms (Pollock and Rindova 2003, Zavyalova et al. 2012). In particular, the media can push regulators to enforce corporate law, question the skills of executives, impose costs on firms by damaging their reputation, or even drive strategic change (Dyck and Zingales 2002, Dyck et al. 2008). As such, the media act as a key information intermediary_or “infomediary" (Deephouse and Heugens 2009)—between firms and the rest of society.

Research on infomediaries has shown that the media act as a political force that scrutinizes corporations to inform the public, and at times their drive for sensationalism makes them scapegoat particular firms and stir scandal to attract attention (Adut 2005). Media signals are essential in the corporate world because they shape perceptions of firms (Westphal et al. 2012) and thereby affect their ability to recruit top talent, to attract and retain valuable customers, and to build a reputation over time (Deephouse 2000). Perhaps even more importantly, since media reports influence firms'subsequent actions (Jonsson et al. 2009), they are directly relevant to firm strategy (Bednar et al. 2013).

While perceived violations of norms likely drive media disapproval of firms, the relationship between the two is not linear (Vergne 2012). This nonlinearity has been particularly visible in relation to the issue of CEO compensation — a hotly debated topic that epitomizes people's fascination for powerful decision makers, as illustrated by the epigraph introducing this paper. Despite the media's monitoring of CEO pay based on what they deem fair or unfair, some firms seem to attract more media disapproval of CEO overcompensation than one would expect—leaving other firms whose CEOs are paid excessively comparatively untouched by public criticism. ${ }^{1}$ In 2002, for instance, the major U.S. media outlets published

\footnotetext{
${ }^{1}$ For the sake of conciseness and readability, in the remainder of the paper, we write "media disapproval" to refer to "media disapproval of CEO overcompensation".
} 
11 articles disapproving of Hewlett-Packard's CEO compensation ( $\$ 13$ million that year) but only three disapproving of Apple’s (despite a $\$ 93$ million package). ${ }^{2}$

To shed light on this intriguing phenomenon, we draw on signaling theory (Spence 1973, Stern et al. 2014) and theorize about a previously overlooked phenomenon, namely signal incongruence. Specifically, we argue that when two salient cues appear incongruent, the media will likely find it challenging to read and interpret them because of the apparent contradiction. As a result, they can become suspicious and instill more disapproval in their stories about the firm. Empirically, we examine how the positive signal of corporate philanthropy (hereafter "philanthropy"), often associated with generosity and altruism (Muller and Kräussl 2011), affects the media's assessment of CEO overcompensation — a negative cue often associated with selfishness and "greed" (Takacs Haynes et al. 2015). Furthermore, we look at the consequences of media disapproval — that is, whether firms reduce CEO compensation in response to disapproval. We argue that, when targeted by the media, firms engaged in philanthropy are more inclined to reduce CEO overcompensation, thereby preserving their established goodwill by mitigating signal incongruence. Our panel data analyses, which cover 2,240 CEOs at 1,477 U.S. publicly listed firms between 1995 and 2006, support our hypotheses. Moreover, we conducted semi-directed interviews with eight leading journalists who cover CEO pay to flesh out the results of our quantitative analyses.

By explaining why certain firms face more media disapproval than others despite their offering comparable CEO pay packages, our study contributes to several interrelated literatures. First, we add to research on infomediaries (Deephouse and Heugens 2009) by demonstrating that discrepancies in media disapproval across firms with similar levels of CEO overcompensation are partly explained by the presence of incongruent cues (i.e., overcompensation and philanthropy), which leads to media suspicion and social sanctions. In turn, this finding contributes to generalizing recent theory on signal congruence (Stern et al. 2014) to situations of signal incongruence and to linking media signals to firms' strategic responses (Bednar et al. 2013, Durand and Vergne 2015)—in our context, decreasing CEO compensation.

\footnotetext{
2 This surprising finding holds after controlling for known antecedents of CEO compensation such as tenure and performance. Both firms compete in the same industry as described by the two-digit SIC code 35. Details are provided in the Methods section.
} 
Besides, our findings pave the way for reconciling two opposing perspectives on firms' prosocial behavior-one that sees actions such as philanthropy as an "insurance" against negative social evaluations (Godfrey et al. 2009), and another that sees such visible actions as providing easy targets for public criticism (King and McDonnell 2015, Rhee and Haunschild 2006). Indeed, in line with the insurance view, we find that philanthropy mitigates negative media evaluations (main effect). But we also find, as per our signal incongruence hypothesis, that philanthropy amplifies the negative effect of CEO overcompensation on media disapproval—a finding that supports the claim that involvement in philanthropy can, under certain conditions, make firms vulnerable in terms of attracting more criticism.

Finally, our study adds to the literature on CEO pay (Bednar 2012, Core et al. 2008, Kuhnen and Niessen 2012) by providing evidence that (some) firms decrease CEO overcompensation in the wake of media disapproval. Our findings thus shed additional light on how the media act as agents of external corporate governance for firms (Aguilera et al. 2015, Hsieh et al. 2018, Walsh and Seward 1990).

\section{HYPOTHESIS DEVELOPMENT}

\section{Firm signals and media disapproval}

Signals are strategic levers that convey information about the firm, thereby influencing how stakeholders evaluate it in situations characterized by uncertainty (Spence 2002). For example, advertising spending acts as a signal of product quality for prospective consumers (Milgrom and Roberts, 1986), and certifications by third parties signal commitment and increase the likelihood of start-up growth (Sine et al. 2007). Key providers of signals about firms are the media, which represent "a special type of stakeholder focusing on the collection and distribution of information" (Deephouse and Heugens 2009: 542). Media organizations, typically forprofit firms that specialize by topic, face specific incentives that can influence their publications' content. As explained by The Economists business editor during a 2005 panel on CEO compensation,

Journalists $[\ldots .$.$] are poorly paid, at least relative to CEOs. Being human, I think that means they are usually$ hostile about large amounts that are paid to other people. This is particularly the case when those journalists come in contact with executives in your own company who you know are incompetent, and, therefore, assume that trend is generally the case across the industry (Bishop et al. 2005: 5)

In other words, although the media thrive on a reputation for reliability and accuracy, they also have their own biases and can generalize particular cases to entire categories of firms (Westphal and Deephouse 
2011). Indeed, as was further explained during the panel, "there's an apocryphal story about a young journalist joining The Economist and asking the editor, 'How do you write in that crisp, opinionated, certain style that The Economist does?' And the answer was, 'Simplify, then exaggerate.”' (Bishop et al. 2005: 3-4).

The media play a key role in shaping the public debate on CEO pay. In the U.S., CEO pay increased by more than 600 percent between 1980 and 2004, while the average worker's pay increased by 7 percent (Bogle 2008) — a growing disparity that the media have not only noticed but also publicized and heavily criticized (e.g., Deutsch 2008). In fact, in her research on redistribution, McCall (2013) "found that the highest level of concern about income inequality coincided with a media focus on executive pay" (Institute for Policy Research 2013). And given the "just world hypothesis", according to which "individuals have a need to believe that they live in a world where people generally get what they deserve" (Lerner and Miller, 1978: 1030), one can expect overcompensation to nurture a perception of unfairness.

Note that, to identify overpaid CEOs, it is not enough to look at raw compensation levels. Indeed, the notion of overcompensation is relative: higher performers deserve higher compensation, and talent scarcity in some industries justifies more attractive packages (Kolev et al. 2017). On the issue of CEO pay, a senior writer at Fortune argues that "what the press can and should do is (a) run the numbers [...] and translat [e] them for the public; and (b) hold companies to their own rhetoric" (Bishop et al. 2005: 3). Robert McCartney of the $W$ ashington Post, during an interview, pointed out that "the [...] greed of executives who were overpaid, compared to their firms' poor performance, was naturally newsworthy". Thus, our baseline hypothesis going forward can be stated as follows:

Baseline Hypothesis: CEO overcompensation (in relative terms) increases media disapproval.

\section{Signal incongruence in context: Overpaid CEOs at firms involved in philanthropy}

Before we develop new hypotheses building on signaling theory, this section discusses the underlying assumptions of signaling theory and explains why we chose to explore our ideas on the negative consequences of signal incongruence in the context of CEO overcompensation and philanthropy.

In the business world, signaling can only be effective to the extent that evaluators (e.g. external stakeholders) attend to and interpret the signals emitted by firms (Madsen and Rodgers 2015, Stern et al. 
2014). So we chose to examine a setting where the issue attracting disapproval (i.e., CEO overcompensation) figured prominently on the agenda of specific stakeholders whose job is precisely to attend to and evaluate the signals emitted by firms—namely, the media. Indeed, as noted by Core et al. (2008: 1), "there are few topics that are more pervasive and produce bigger headlines in the business press than executive compensation". Also, we deliberately chose a context involving media scrutiny of a contested business practice so we could examine the negative end of the social evaluation spectrum, i.e., disapproval (Vergne 2012). Indeed, research in social psychology and on signaling have both demonstrated that, "when confronted with negative behavior, people will spend more time thinking about it than positive or neutral behavior, [and] they will search more extensively for causal information" (Lange and Washburn 2012: 301).

Given our focus on CEO overcompensation, we were looking for a "paired" signal that would provide a clear counterpoint to the perception of "selfishness" or "greed" typically associated with excess CEO pay (Takacs Haynes et al. 2015). In addition, we were looking for a signal that the media pay attention to and for which data are available at a low cost, as these are assumptions of signaling theory. To identify signals meeting these requirements, we looked for cues emitted by firms associated with "altruism" and "generosity"- the opposite of "selfishness" and "greed". Following a review of the literature on firms' prosocial behavior and discussions with colleagues, "philanthropy" emerged as our best option. Corporate philanthropy is "defined as voluntary and unconditional transfers of cash or other assets by private firms for public purposes" (Gautier and Pache 2015: 343). It "involves the allocation of time, money, or goods aimed at addressing a social need" (Muller et al. 2014: 1) and "signals a willingness to act altruistically (other considering) as opposed to purely agonistically (self considering)" (Godfrey et al. 2009: 427). A common way in which philanthropy manifests itself is through charitable giving, but philanthropy also includes initiatives such as support for education, corporate volunteering, and in-kind contributions (Gautier and Pache 2015).

The idea that philanthropy and overcompensation are often perceived as incongruent was further supported by searches in the Factiva media database, which can display the terms most often associated with particular keywords across thousands of news articles. These analyses, reported in Appendix A, further demonstrate that philanthropy and overcompensation represent instances of a positive and a negative signal 
(respectively), located at the two extremes of a semantic scale that ranges from altruism/generosity to selfishness/greed. This is precisely what makes them incongruent to our audience of interest— the media, which arguably reflect broader societal perceptions as well.

To refine our understanding of signal incongruence, we draw on the "cognitive-linguistic perspective", which shows that "specialist stakeholders provide more negative evaluations when the firm is a decoupler" (Crilly et al. 2016: 717), because specialists have the necessary topical expertise to identify discrepancies (e.g., between discourse and actions). ${ }^{3}$ We thus decided to complement our data with eight interviews with expert journalists who authored some of the media reports on CEO pay in our dataset.

\section{Theory development: Signal incongruence and disapproval}

Media organizations can simultaneously be seen as emitters of signals about firms and as interpreters of signals emitted by firms (Deephouse 2000). In line with signaling theory (Spence 2002), our guiding assumption for this study is that signals are neither interpreted nor emitted one at a time. As argued by Stern et al. (2014), when firms emit multiple congruent signals over a short period of time, stakeholders such as the media will match the firms with preexisting "prototypes" in the industry, resulting in clear-cut, mutually reinforcing evaluations. These prototypes can produce spillover effects and set broad expectations about firm behavior-a phenomenon that could subsequently create disappointment and disapproval when the expectations are not met. We thus extend Stern et al. (2014) to situations of signal incongruence and expect, by contrast, that incongruent cues sent by a firm create an interpretation challenge for its stakeholders, leading to lower social evaluations of the firm. To develop our argument, we build on two related literature streams that draw respectively on social-psychological and cultural explanations.

\footnotetext{
${ }^{3}$ Crilly et al. demonstrate that "decoupling does not necessarily involve intent on the part of managers. Rather, decoupling can be the outcome of organizational learning efforts that are fraught with complexity" (Crilly et al. 2012: 1430). In addition, there can be situations where "decision-makers may not know how to keep the promises they make" (Crilly et al. 2016: 707). This implies that incongruence is not always the result of deliberate attempts to deceive stakeholders. So, rather than speak of managerial cynicism, deceit, or hypocrisy - all of which involve some form of incongruence between discourse and actions-we prefer the more neutral "signal incongruence", which remains agnostic about managerial intentions but can nevertheless be expected to upset external stakeholders such as expert journalists. To be sure, observers may infer that incongruence is driven by hypocrisy-and the journalists whom we interviewed occasionally spoke of hypocrisy—but such an inference is not necessarily accurate, as shown by Crilly et al (2012). Put differently, hypocrisy always implies signal incongruence, but the inverse is not true. Our focus on signal incongruence thus makes our theory more generalizable.
} 
First, research in social psychology has examined how stakeholders form judgments when they perceive incongruent cues. The literature on impression formation about character has demonstrated that "positive cues, such as good behavior, may merely be an indication of conformance with societal expectations and norms, thereby conveying relatively ambiguous or equivocal information about underlying attributes" (Mishina et al. 2012: 462). That's why "negative cues are viewed as more diagnostic and thus given greater weight than positive cues" (Mishina et al. 2012: 462, Skowronski and Carlston 1989). This alone could explain the existence of disapproval in the presence of incongruent cues about character. But it also explains why a positive cue cannot easily compensate for a negative one, or why it is more effective, to reduce incongruence, to diminish the intensity of the negative cue rather than that of the positive one. Furthermore, socialpsychological research on categorization and prototypes has consistently shown that straddling incompatible categories results in social sanctions (Zuckerman 1999). Indeed, "when making an evaluative judgment [...], people will first try to categorize the [entity] based on easily categorizable attributes [and w] hen a category is selected, the evaluating person will check the fit between this category and other available attributes on the basis of a category prototype" (Stern et al. 2014: 517, Fiske et al. 1987). When a mismatch is observed—as is the case in the presence of incongruent signals — the evaluated entity will be perceived as failing to fit established category prototypes, resulting in lower social appeal and negative evaluations (Hsu et al. 2009). Moreover, as noted by Vergne and Wry (2014: 71), the effects of category straddling tend to be more pronounced when the "categories have high contrast" (i.e., are seen as incompatible) or "high saliency" (i.e., are highly visible), and "when an organization straddles more than its peers" (i.e., intensity matters). The context of our study is closely aligned with these characteristics, since we examine firms that simultaneously elicit perceptions of selfishness and altruism (to various extents) about their character based on two practices widely discussed in the media, namely CEO overcompensation and philanthropy. In addition, we have previously provided anecdotal evidence that journalists are encouraged to rely on categorical generalizations to write impactful papers, which is likely to make the discussed mechanisms even more salient.

Second, research on institutional logics, understood as the "broader cultural templates that provide organizational actors with means-ends designations" (Pache and Santos 2010: 457), has emphasized the 
challenges that can result from the existence of competing demands embedded in distinct institutional orders. For instance, Marquis and Lounsbury (2007) showed that entrepreneurs resisted acquisitions in the banking sector only when the latter implied a clash between the market logic of global banks (on the acquirer side) and the community logic of local banks (on the target side). Clash between logics happens because distinct logics (e.g., community, market, state, family) "represent different repertoires of justifications that individuals and organizations use to [...] rationalize their choices" (Thornton et al. 2015: 11) and give them legitimacy in the eyes of the public. As such, when the same firm draws on multiple logics to justify its behavior, these incongruent cues risk being interpreted as “opportunistic" (Orlitzky 2013: 213) or "cynical” (Deephouse and Suchman 2008: 60) managerial attempts to distort information about the firm's strategy (means) and ultimate objectives (ends) — independently of whether this is the case or not. Multiple incompatible interpretations of the firm's behavior could ensue, potentially raising suspicion, and leading to more negative evaluations. This is especially true when the conflicting logics are made salient to the public (Nigam and Ocasio 2010), as is the case with issues frequently covered in the media. Interestingly, in the context of this study, CEO (over)compensation is typically justified using a market logic (e.g., "supply and demand primarily determine the amount of compensation [...] receive[d in] the U.S. market for corporate executives", Kay and Van Putten 2008: 3). By contrast, philanthropy is often justified using a community logic ("philanthropy is about community", Cohen 2011: 1), so when both CEO overcompensation and philanthropy are present, a clash similar to the one observed by Marquis and Lounsbury (2007) is likely to occur between the market and community logics.

Interviews with journalists further confirmed that the simultaneous presence of one positive and one negative cue was not sufficient to create a damaging perception of incongruence- the two cues must be found to be at odds at a deeper level, where they epitomize a contradiction between values positioned at the two extremes of the same spectrum. For instance, Sandra Guy of the Chicago Sun-Times told us:

Whether a specific $[\ldots]$ conduct would be viewed as hypocritical behavior together with the company overcompensating their top managers would depend on the specific context. For example, overcompensation would probably not be viewed in a particular negative way in case of Macy's selling products from projects bringing African women into work. However, tying donations to big bonuses [...] might be more likely to be perceived in a negative way. 
In other words, it is because overcompensation is negatively perceived and evokes selfishness that it appears incongruent with philanthropy (which is positively perceived and evokes altruism). On the other hand, contributing to the empowerment of African women would appear more clearly incongruent in the presence of, say, a class action for racial or gender discrimination in the firm's home country. In fact, another journalist who wrote for Bloomberg (and wishes to remain anonymous) told us a story along these lines:

Take the Deutsche Bank and their diversity efforts. The bank is continuously listed as one of the best places to work [...] And they get a lot of appraisal for their diversity efforts and programs. But then I see that Deutsche Bank gets an unusually high amount of litigation by women, indicating that Deutsche Bank is not such a great place to work for women after all.

The Bloomberg journalist also explained that a "story becomes more powerful with th[is kind of] contrast", that is, when a positive and a negative cue relate to the same social domain (e.g., altruism vs. selfishness). More generally, our interviews also confirmed that publicizing instances of signal incongruence was of particular interest to the media, since it aligns well with their role as corporate watchdogs. Pulitzer-prize winning Gretchen Morgenson, of The New York Times, summed this up very well when she told us that a "situation in which hypocritical behavior is exposed is always a good story".

At a theoretical level, one should note the convergence between arguments stemming from the institutional logics and categorization literatures when it comes to explicating the mechanisms that underpin signal incongruence. Specifically, because an institutional "logic is stored via schemas, which are filters that enable managers to efficiently categorize an event [...] and consider appropriate actions" (Thornton et al. 2015: 13, emphasis added), the logics and categorization lenses overlap in their predictions about the consequences of mixing incongruent templates—with the institutional logics lens drawing primarily on cultural explanations, and the category lens primarily on social psychology. These two related literatures lead us to expect signal incongruence to adversely affect social evaluations. Formally:

Hypothesis 1: In the presence of CEO overcompensation (a negative signal associated with selfishness/greed), philanthropy (a positive signal associated with altruism/generosity) is perceived as incongruent and amplifies the effect of CEO overcompensation on media disapproval.

\section{Theory development: Firm response to media disapproval in the presence of signal incongruence}


CEO overcompensation creates a perception of unfairness which represents a cost for firms that can create dissatisfaction among other stakeholder groups and can lead lower-level managers to leave the firm (Wade et al. 2006). Investors could also perceive overcompensation as a sign of poor corporate governance (Joe et al. 2009). Moreover, studies on infomediaries have consistently emphasized that media disapproval leads to negative consequences for firms, such as difficulties in acquiring resources (Weber et al. 2009) and in maintaining relationships with interlocking board members (Sullivan et al. 2007), suppliers (Jensen 2006), and customers (Jonsson et al. 2009). More generally, it is now widely acknowledged that media reputation represents a strategic resource associated with increased performance (Deephouse 2000), so one would expect (at least some) firms to take action in response to media disapproval.

As highlighted on many occasions in studies of "impression management" tactics, firms have strong incentives to avoid having their name tarnished any further and to restore their reputation by responding to media disapproval proportionately — that is, the stronger the disapproval, the stronger the response (e.g., Durand and Vergne 2015). Specifically, prior research has documented a variety of available firm responses, such as denying the facts, emphasizing positive organizational attributes, framing the situation to attenuate negative perceptions, and accepting responsibility (Bansal and Clelland 2004; Elsbach and Kramer, 1996; Pfarrer et al. 2008). In our context, firms led by overcompensated CEOs and engaged in philanthropy epitomize a situation of signal incongruence that may render ineffective several impression management tactics: the reported facts can hardly be denied (i.e., compensation data are publicly available), an emphasis on positive attributes risks amplifying media disapproval as per our signal incongruence hypothesis, and framing implies a public justification that every dollar in a multimillion-dollar pay package was well deserved—at best a perilous public relations exercise.

In the H-P case mentioned above, "H-P shot back and said that [CEO] Fiorina was paid below market average" (New York Post, 27 Feb 2002). But a public statement alone can be seen as lip service, which is why firms often turn to "technical responses [...] that have the potential to address the causes of wrongdoing" in order to restore goodwill (Zavyalova et al. 2012: 1080). By directly mitigating the source of the concern, firms could achieve more favorable outcomes than with a merely symbolic or rhetorical 
response. In fact, the literature on social judgment formation suggests that, in situations wherein firm character is being evaluated, negative cues are the most diagnostic and reducing them should therefore be the focus of the firm's response (Mishina et al. 2012). In our context, this suggestion implies that the criticized firms that are engaged in philanthropy should seek to reduce CEO overcompensation in subsequent periods more than other firms. This is because firms engaged in philanthropy are more exposed to allegations of cynical or opportunistic behavior based on the incongruent cues they emit (Orlitzky 2013). In fact, firms are often aware of the damaging effects of prosocial actions (e.g. philanthropy) that are not perceived as genuine or legitimate, and managers clearly have "instrumental motives to pre-empt bad publicity" in these situations (Aguilera et al. 2007: 845; Pfarrer et al. 2008). Furthermore, firms engaged in philanthropy are typically seeking to establish a reputation as a good corporate citizen, and they will therefore be enticed to protect that valuable "stock of social capital" or "reservoir of goodwill" (Zavyalova et al. 2016: 257) accumulated over time by addressing the cause of media criticism. By decreasing the amount of excess CEO pay in response to media disapproval, a firm could then be perceived to accept responsibility by taking action— not by using rhetoric. ${ }^{4}$ This would weaken both the direct negative effect of CEO pay on media disapproval (baseline hypothesis) and the amplification effect caused by signal incongruence (H1). Put simply, by alleviating signal incongruence, the reputational capital accumulated through philanthropy could be perceived as more genuine and less opportunistic. And, as argued in prior research on wrongdoing, the firm's response tends to be proportionate to the extent of the perceived wrongdoing (Pfarrer et al. 2008). Formally:

Hypothesis 2: The more a firm is engaged in philanthropy, the more it reduces CEO overcompensation in response to targeted media disapproval. The firm's response will be stronger for higher levels of CEO overcompensation.

\section{EMPIRICAL SETTING, DATA, AND MEASURES}

\section{Period of study}

We chose to begin our sample in 1995 based on sufficient media attention to CEO overcompensation and philanthropy, and to end data collection in 2006. CEO pay did not become a public

\footnotetext{
${ }^{4}$ Our study, however, does not directly measure board of directors' intent, though our models control for various characteristics of board composition, such as $\mathrm{CEO} /$ chairman duality or the number of directors working at media organizations. Future research could rely on interview and survey data to relate board intent to the heterogeneity of firm responses to media disapproval.
} 
issue until the mid-1990s following the publication of Graef Crystal's (1991) exposé on CEO pay, In Search of

Excess. Robert McCartney of the Washington Post recalled this period during an interview with us:

When I came to New York in the 1990s to cover Wall Street for the Washington Post, I was one of the first to cover the topic of CEO compensation, following Graef Crystal [...] The overall impression was that CEOs were paid for low performance [...] The institutional investors representing unions and workers' pensions started to get interested in the issue, and on their behalf, the Council of Institutional Investors became active. Politicians joined in.

When looking at temporal patterns of media attention to CEO overcompensation in the 1990s, we noticed a sharp increase starting in 1995, which also coincides with the beginning of a steady increase in attention to philanthropy (see Figure 1 below). That's why we picked 1995 as the beginning of our observation window, in line with the assumptions of signaling theory.

\section{--- Insert Figure 1 bere ---}

We stopped data collection in 2006 because, starting in 2007: 1/the revised Financial Accounting Standard changed disclosure rules for CEO pay, and related 'Say on Pay' regulation started to be implemented by firms on a voluntary basis, thereby creating unobservable heterogeneity; 2/ our source of philanthropy data, MSCI Kinder Lydenberg Domini (KLD), adopted a new measurement methodology, which makes preand post-2007 data difficult to compare; 3/ Twitter became fully operational, alongside other social media platforms, thereby creating a need to account for a new source of media disapproval that is difficult to compare to pre-2007 newspaper sources (in fact, the growing influence of social media on firm behavior should probably be analyzed as a topic on its own in a separate study).

\section{Data sources}

In terms of quantitative data, we used CEO compensation data from ExecuComp ${ }^{5}$, which we matched to the Center for Research in Security Prices (CRSP)/Compustat database (for financials), to the KLD database (for philanthropy), and to the Factiva database (for media disapproval). We included a firm in the sample when we had complete information on CEO compensation and philanthropy, and when the firm was both covered by KLD and clearly identifiable in Factiva. The final sample consists of 2,240 CEOs at 1,477 publicly listed firms

\footnotetext{
${ }^{5}$ Brookman et al. (2006) systematically compared the top three research databases for executive compensation, namely Standard \& Poor's Execucomp, Forbes' Annual Compensation Survey, and the Wall Street Journal's CEO Compensation Survey. They find that "most of the values of overlapping compensation data are relatively similar across all three compilations", though "Forbes' estimate of option values may bias results of studies that use it" (Brookman et al. 2006: 27-28). They conclude by writing that their study "supports the current widespread use of Execucomp in leading compensation research" (Brookman et al. 2006: 1).
} 
from the S\&P 1500, covering the years 1995 to 2006. Due to KLD’s expanded coverage from 2001 onwards, we were able to match data from ExecuComp, Compustat, and KLD for more firms after that date (62 percent for 2001-2006 vs. 43 percent for 1995-2006). To check whether this change in the matching process could bias our findings, we conducted a robustness test after excluding 1995-2000 data. It is reported in Appendix B and shows that our results are consistent with the full estimates obtained over the entire period - in particular, p-value thresholds are identical for the coefficients of interest and effect sizes are similar across most pairs of coefficients. This means that the forced exclusion, from our analyses, of firms with missing data in either Execucomp or KLD does not affect our findings in any significant way.

We complemented these data with qualitative interviews to further validate our theoretical development, triangulate our results, and flesh out our findings with illustrative quotes. Using media disapproval data, we identified twelve expert journalists who had written at least ten articles on CEO compensation at leading publications (e.g., The New York Times, Washington Post), and contacted them by email or through LinkedIn. Out of the nine who initially replied, seven accepted to be interviewed on the phone (5 interviews) or by email (2 interviews). One journalist referred us to Sarah Teslik, the former executive director of the Council of Institutional Investors, with whom we conducted an eighth interview on the phone. Our interviews were semi-directed, and included general questions about CEO (over)compensation, and the various data sources and factors motivating the media to target particular companies over others.

\section{Dependent variable: Media disapproval}

Our dependent variable captures the media's negative evaluations of firms' CEO pay (hereafter, media disapproval). In line with prior research on media evaluations (Bednar 2012; Bednar et al. 2013; Deephouse 2000; Pfarrer et al. 2010; Pollock and Rindova 2003; Zavyalova et al. 2012), we measure media disapproval as the relative prevalence of a negative evaluation over all media evaluations. To do so, we first used a search strategy similar to Core et al. (2008) to locate all Factiva articles that cover CEO compensation irrespective of the tone. We measured media coverage in the year following compensation disclosure because the media report on pay based on information published in annual reports. We then evaluated the tone of an article using an automatic Python script that identifies negatively connoted keywords within a range of, at most, 32 
words between a CEO's name and words related to compensation. ${ }^{6}$ An article was classified as having a negative tone if the script detected a negative keyword. The relative prevalence of negative media evaluations of CEO pay was then calculated as the sum of all negative articles divided by the total number of articles that covered a CEO's pay in a given year. Altogether, the search resulted in 12,573 unique articles of which approximately one-third were determined to have a negative tone. The search string and a list of keywords used for the search are provided in appendices C and D. ${ }^{7}$ Thus, the variable takes values between 0 and 1 , representing the proportion of negative coverage received yearly by a given firm. Using a count variable for media disapproval instead of a proportion did not affect our results (see Supplementary Analyses below).

\section{Independent variables}

CEO overcompensation is a deviation from a norm that signals excessive remuneration levels, which we operationalized through a well-established and widely used procedure (Core et al. 2008, Wade et al. 2006, Wowak et al. 2011). First, we calculated CEO compensation as the (logged) total annual value of all salary, bonuses, restricted stock grants, long-term incentive-plan payouts, and option grants valued using the BlackScholes formula, and all other income paid to a CEO. We then calculated anticipated CEO compensation through annual cross-sectional regressions of the natural logarithm of total pay on an array of well-proven economic determinants of compensation (including industry controls, see Appendix E). Residuals of the annual regressions capture CEO overcompensation.

Philanthropy was measured using KLD data, collected from "annual questionnaires sent to company's investor relations office, firms' financial statements, annual and quarterly reports, general press releases, government surveys, and academic journal publications" (Flammer 2015: 2557). This data-sourcing

\footnotetext{
${ }^{6}$ The narrow range of words for the indicators of CEO pay and the negative tone to appear after the CEO's name enabled us to establish a fairly direct connection between the CEO, his or her compensation, and the negative signal. The list of negative signal words was gleaned from Core et al. (2008) and specific to the topic of executive remuneration. We randomly checked approximately 300 articles to assess whether the list in Core et al. (2008), which covers articles until the year 2001, was still valid for later years or had changed significantly. We did not find any substantial differences in the wording of the articles contained in our sample.

${ }^{7}$ Media coverage of CEO pay in our sample and in related research is almost never positive (e.g., Core et al. 2008); i.e., remaining articles were almost exclusively neutral in tone. We tested how the automated script performed, compared with human coding, by having two human coders independently rate articles on 50 randomly selected CEOs. In contrast with the automated script, the range of words for the indicators of compensation and a negative tone were not restricted. Human coders and the script agreed in 74.3 percent of articles, with the script underestimating the amount of negative coverage. We then used the cases in which the human coders and the script disagreed as the dependent variable in a regression that included our controls variables. None of them was found to be statistically significant, meaning that disagreement was randomly distributed, and thus, not a concern for this study. Our coding procedure, validated by this robustness check, follows that of Core et al. (2008) and Carberry and Zajac (2017).
} 
strategy is superior to content-analyzing firms' annual reports alone, because "it is not obligatory for firms to disclose their philanthropic activities" in these reports—in fact, they don't always do so (Su and Sauerwald 2015: 9), and typically use various channels to communicate on philanthropy-related activities. A total of eight KLD items are related to philanthropy (Charitable Giving, Innovative Giving, Non-US Charitable Giving, Support for Housing, Support for Education, Indigenous Peoples Relations, Volunteer Programs, Other Strengths). Each item is assigned to a binary measure, and firms are awarded a 1 ("strength") if they fulfil specific criteria. The scores are then summed to provide an overall evaluation for the category. Interestingly, "because one group [of KLD research analysts] is doing the ratings, using an objective set of screening criteria, the ratings are applied consistently across all companies and are replicable" (Graves and Waddock 1994: 1039). KLD data are widely known and easily accessible, which explains why they "have been extensively used by researchers and practitioners alike", including journalists (emphasis added, Kacperczyk 2009: 269). While our KLD-based measure of philanthropy is much richer and more consistent (across firms and over time) than simple measures of cash donation amounts, Cheng, Hong and Sue (2015: 12) found in regression analyses that "equal-weighted KLD scores predict donations well in annual levels". For all these reasons, KLD data are considered "the de facto research standard" for measuring prosocial behavior (Waddock 2003: 369). We thus computed philanthropy as the sum of "strengths" identified by KLD across all philanthropy-related items (Gautier and Pache 2015; the sum of "concerns" is included as a control variable). Note that none of our main variables (i.e., CEO overcompensation, media disapproval, philanthropy) are coded in a binary fashion because we acknowledge upfront that signals are not just present or absent, but can vary in strength.

\section{Control variables}

We controlled for firm size (total assets, logged), firm age (number of years since IPO plus one, logged), and captured whether the firm was one of Fortune's "Most Admired Companies" in a given year using a binary indicator. Firms that are larger, older, and better known in their industry tend to have a stronger media appeal (Vergne 2011). To account more specifically for media visibility, we measured the log of the total number of Factiva articles mentioning a firm's name in the preceding year (excluding CEO pay related articles). We 
further controlled for the number of stock market analysts following the firm. Past research indicates that equity analysts potentially influence other information intermediaries and stakeholders (Pollock and Rindova 2003, Zuckerman 1999). We capture two dimensions of firm performance by including returns to shareholders (a forward-looking measure) as well as returns on assets (a backward-looking measure). The correlation between the two variables is relatively low $(0.16$, see Table 1$)$ and including both is standard practice in empirical studies of executive compensation in finance and economics (e.g., Core et al. 2008). Following recommendations made in prior works, we controlled for a firm's potential weaknesses in the area of philanthropy using the number of "concerns" flagged by KLD in relation to the eight items used in our measure (Mattingly and Berman 2006). Our last firm-level control is shareholder activism, computed as the number of shareholder sponsored proposals up for voting at annual meetings (logged). These data come from RiskMetrics and SEC filings.

We controlled for CEO tenure (a longer tenure implies that the public is more familiar with the CEO and the media more likely to write about her/him); whether the CEO is the founder of the firm (past research suggests systematic differences in the composition and level of compensation between founder and nonfounder $\mathrm{CEOs})^{8}$; whether the $\mathrm{CEO}$ is female (this could bias media evaluations); and CEO duality, present when a CEO also serves as chairman of the board (duality could compromise the board's ability to implement optimal CEO compensation). We also control for the level of CEO compensation that can be anticipated based on a set of well-known economic determinants (see CEO overcompensation measure above). Since anticipated CEO compensation could potentially affect both actual compensation levels and media disapproval (e.g., journalists might self-select into targeting particular CEOs based on anticipated pay levels), including this variable mitigates the issue of omitted variable-induced endogeneity (Bascle 2008).

Finally, we included year dummies to control for time-varying, unobserved variables (e.g., the public perception of CEO pay), and industry dummies based on 2-digit SIC codes to control for persistent differences across sectors (e.g., media appeal). Table 1 below displays summary statistics and correlations.

\footnotetext{
8 To identify Founder CEOs, we looked up the 112 CEOs who had been in place for more than 5 years in the BoardEx database. Of these, 73 were listed as (co)founders. For CEOs not listed in BoardEx, we used data sources such as profile pages on the Notable Names Database and the Bloomberg, Businessweek, Forbes, and Wikipedia websites, and identified another 13 CEOs as founders.
} 


\section{EMPIRICAL ANALYSES}

\section{Estimation method}

Two-stage equations. Our models use ten instrumental variables to correct in various ways for the potential endogeneity stemming from systematic, unobserved differences between firms that overcompensate their CEOs, engage in philanthropy, or get targeted by the media — and firms that do not. Each of the three important predictors in our models is instrumented using either a Heckman procedure with exclusion restrictions, a two-stage least-squares instrumental variables regression, or both. All relevant details can be found in Appendix F.

Estimators and standard errors. Since our dependent variable "is a fraction bounded between 0 and 1, we follow Papke and Wooldridge (1996) and estimate [our model] using a general linear model (GLM) in which the link function is logistic. Papke and Wooldridge show that this estimator is consistent when the dependent variable is a proportion ranging from 0 to 1 , and when there may be a mass of observations at 0 and 1" (Core et al. 2008: 9-10). Accordingly, we used STATA’s "glm, family(binomial) link(logit)" to confirm the baseline hypothesis and test H1. Coefficients of our GLMs represent the change in the log-odds of the outcome for a one-unit increase in the predictor variable, independently of other variables included in the analysis.

To test hypothesis 2 and to assess whether overcompensation decreases in the year following media disapproval, we first performed a two-stage least-squares (2SLS) regression of CEO overcompensation $_{t+1}$ using three instruments (see Appendix F), followed by fixed-effects panel regressions of CEO overcompensation ${ }_{t+1}$ that include the inverse Mills ratio to correct for selection-driven endogeneity. We chose a fixed-effects specification based on a Hausman test (i.e., the heteroscedasticity-robust Sargan-Hansen statistic yielded $p<0.01)$. Because our data are organized by firm-year, the residuals may exhibit autocorrelation and positive cross-sectional correlation. To mitigate this potential issue, we used Huber-White heteroskedasticity-robust standard errors clustered at the firm level.

\section{Hypothesis testing}


Table 2 above lists the results of our test of $\mathrm{H} 1$ and Table 3 below reports our tests of H2. Model 1 reports the selection equation for CEO overcompensation. Model 2 contains controls only and is used to confirm the validity of our baseline hypothesis. Model 3 tests hypothesis 1 after correcting for endogeneity related to CEO overcompensation. Model 4 reports the selection equation for philanthropy. Interestingly, our two performance variables are not positively associated with philanthropy, a result that contrasts with Margolis et al. (2007), who note that "firms that perform [...] tend [...] to donate more money". Model 5 and 6, respectively, reproduce the results of models 2 and 3 after correcting for endogeneity related, this time, to philanthropy. In both model $2(\mathrm{p}<0.001)$ and model $5(\mathrm{p}<0.05)$, CEO overcompensation increases media disapproval, and a one-unit increase in overcompensation increases the odds ratio of disapproval by a factor comprised between $2.61(\exp (0.96))$ and $2.01(\exp (0.70))$. To understand the implication of this relationship in terms of predicted probabilities for an average firm, consider a CEO who is paid what s/he "deserves", i.e., with zero overcompensation. According to our most conservative estimates (from model 5), the predicted mean value of disapproval would then be 8.92 percent. Add five million dollars in overcompensation (i.e., roughly one S.D.), and the predicted value of disapproval grows to 15.3 percent.

In models 3 and 6 , we add the interaction term between the two incongruent signals. Corresponding coefficients are highly significant and in the hypothesized direction $(1.45<\beta<1.54, p<0.001)$. The predicted mean value of disapproval for a firm low on philanthropy and high on CEO overcompensation ( $\$ 5$ million) is 13.8 percent, but increases to 37.0 percent when the philanthropy score is high. This is consistent with our earlier example about HP and Apple in 2002_indeed the former had a philanthropy score of 1 in 2001 and 2002, and of 3 in 2003, whereas the latter, much less disapproved of, had a score of zero. Overall, H1 receives strong support: In the presence of CEO overcompensation, philanthropy is perceived as incongruent and amplifies the negative impact of overcompensation on disapproval. Figure 2 below plots the joint impact of the two variables on media disapproval using estimates from model 6.

$$
\text { ---- Insert Figure } 2 \text { here ---- }
$$

$\mathrm{H} 2$ states that the more a firm is engaged in philanthropy, the more it reduces CEO overcompensation in response to media disapproval. It also states that the response will be stronger at higher 
levels of CEO compensation. In model 7 (see Table 3 below), we begin to test H2 by performing a 2SLS regression to assess the effect of media disapproval on CEO overcompensation $t_{t+1}$ after correcting for endogeneity using three instrumental variables (see Appendix F). We find a significant and negative effect $(\beta=$ $-0.72 ; \mathrm{p}<0.01)$. The same model computed without instrumental variables yields $\beta=-0.32(\mathrm{p}<0.01)$, which alleviates concerns that the directionality or significance level of our estimates of media disapproval's effect are affected by endogeneity. In fact, not using the instruments yields a more conservative estimate of media disapproval's effect. In model 8, we then estimated a Probit selection equation predicting media disapproval using the number of media directors $(\beta=0.12 ; \mathrm{p}<0.05)^{9}$, the number of analysts following the firm $(\beta=0.15$; $\mathrm{p}<0.001)$, and the median distance between a firm's and media organizations' HQs $(\beta=0.00 ; \mathrm{p}<0.001)$ as exclusion restrictions. Then, in model 9, we regress CEO overcompensation $t_{t+1}$ on our control variables. In model 10, we add the three possible two-way interaction effects as additional controls, as suggested in the literature (Dawson and Richter 2006) and implemented in recent research (e.g., Younge et al. 2015). Finally, in model 11, we add the three-way interaction between CEO overcompensation, philanthropy, and media disapproval to test $\mathrm{H} 2$ per se. The coefficient of the combined effect is negative and statistically significant $(\beta=-0.24$, $p<0.05)$, and model 11's adjusted $\mathrm{R}^{2}$ increases relative to model 10 —even though adjusted $\mathrm{R}^{2}$ accounts for the loss of one degree of freedom. This provides support for H2: the more a firm is engaged in philanthropy, the more it reduces CEO overcompensation in response to media disapproval (and even more so at higher levels of CEO overcompensation). ${ }^{10}$

\section{---- Insert Table 3 here ----}

Figure 3 below plots the marginal effect of media disapproval on CEO overcompensation $t_{t+1}$ for a meaningful range of values taken by philanthropy [0; mean+1 S.D.] and overcompensation [0; mean+2 S.D.]. To further illustrate our findings, consider a CEO overcompensated by $\$ 5$ million and targeted intensively by

\footnotetext{
${ }^{9}$ Gurun (2016) finds that firms with media directors receive, in general, more media coverage and less negative coverage. Our finding, obtained in the context of coverage related to CEO overcompensation, suggests that the impact of media directors might depend on the topic. This represents an interesting avenue for future research.

${ }_{10}$ We thank an anonymous reviewer for suggesting that a two-way interaction between media disapproval and philanthropy might be sufficient to test H2. In a supplementary analysis (available upon request), we found $\beta=-0.21(p<0.01)$ for that two-way coefficient. This lends further support to the idea that firms involved in philanthropy decrease CEO compensation following media attacks. A three-way interaction, though more cumbersome to implement, has two merits: first, it accounts for the idea that firm response intensity should increase with the severity of the initial norm violation; second, it lets us discount the interaction effect by setting CEO overcompensation to zero when there is in fact no overcompensation-allowing us to empirically capture the fact that, at times, the media target an "innocent" firm.
} 
the media. At a firm "low" on philanthropy, overcompensation would decrease by 40 percent in $\mathrm{t}+1$, down to $\$ 3$ million. At a firm "high" on philanthropy, the decrease would be stronger (-119 percent), and, in fact, CEO overcompensation would disappear altogether in $\mathrm{t}+1$. Note that, following high overcompensation, a decrease is generally expected due to mean reversion (Wowak et al. 2011). However, our study accounts for mean reversion in model 11 by including CEO overcompensation as a control variable (Core et al. 2008), so what our results show is the effect of media disapproval above and beyond that of mean reversion. ${ }^{11}$

---- Insert Figure 3 bere ----

\section{Robustness Tests and Supplementary Analyses}

Zero overcompensation. Model 12 in Table 4 below re-tests $\mathrm{H} 2$ after setting CEO overcompensation to zero in the situations where it takes on negative values. We do this to capture two related ideas: $1 /$ the media could mistakenly disapprove of a CEO who is in fact undercompensated; 2/ firms that do not overcompensate their CEOs have no (market-based) reason to decrease that (non-existing) overcompensation, independently of whether the firm is disapproved of. When these situations arise, our interaction effect should take a value of zero because it should not trigger a decision to decrease (a nonexisting) overcompensation. Based on this alternative coding of the variable, model 12 uses a Tobit estimator which accounts for left-censoring (i.e., negative values recoded as zeros). The results remain the same, and the three-way interaction becomes even more significant (1 percent instead of 5 percent). Taken together, these results add further support to $\mathrm{H} 2$.

\footnotetext{
${ }^{11}$ Due to the existence of a payout schedule for stock options, compensation tends to revert to the mean after realizing high values. The schedule agreed upon initially between the CEO and the board could drive both media disapproval and decreases in overcompensation (e.g., if the media criticize a firm when overcompensation is high and that firm's schedule plans for a big payout in, say, 2018, then media disapproval will likely be high in 2018, and compensation will revert to the mean in 2019 without media disapproval causing the reversion). As such, endogeneity could be a concern if one omitted a variable that affected both the predictor (media disapproval) and dependent variable (decrease in overcompensation $\mathrm{t}_{\mathrm{t}+1}$ ). Note, however, that: 1 /stock option payouts depend, to some extent, on performance, which we control for using two direct indicators as well as a measure of anticipated CEO compensation, computed in a way that captures how much a CEO should be paid given her current level of performance; $2 /$ the omitted variable bias (i.e. not accounting for the pre-existing schedule of stock option payouts) is firm specific and, once agreed upon, does not vary over time. Our firm fixed-effects would capture that; 3 /we control for mean reversion by including past CEO overcompensation in our models, in line with Core et al. (2008); 4/we instrument media disapproval using three variables (see model 7 in Table 3), and the effect still holds; and 5/if the only effect at play was an acceleration of mean reversion caused by media disapproval, then the main effect of media disapproval on decreases in CEO overcompensation $_{t+1}$ would disappear once we control for the interaction between media disapproval and CEO overcompensation (which would readily capture the "acceleration"). In a test available upon request, we find no support for the acceleration hypothesis $(\beta=-0.00 ; \mathrm{p}>0.9$ on the interaction term); the main effect of media disapproval remains significant $(\beta=-0.30, \mathrm{p}<0.05)$. Arguably, this means that mean reversion is independent from the effect of media disapproval.
} 
Alternative measure of disapproval and fixed effects. Instead of measuring disapproval as the proportion of negative to total CEO pay coverage (after controlling for media visibility), we measured it as a discrete variable counting negative articles, ranging from 0 to 58. Accordingly, we re-estimated our model using a negative binomial specification, appropriate for count dependent variables, and included firm fixed-effects alongside robust standard errors (Hausman test gave $p<0.01$ ). Model 13 in Table 4 reports the results. They provide the same level of support to $\mathrm{H} 1$, but more control variables become significant at the $5 \%$ level (or less), including media visibility, return on assets, and CEO tenure. But the addition of fixed-effects forces us to drop half of our observations (i.e., firms whose CEOs are never disapproved of in the media) and may intensify sample selection bias, which is why we prefer the original specification reported in models 3 and 6 . Unpacking philanthropy. To unpack the effect of philanthropy, we re-tested H1 after distinguishing between charitable giving (cash donations captured by three KLD items out of eight) and other forms of philanthropy (the other five KLD items). These latter forms of philanthropy may be less visible to external stakeholders such as the media, and model 14 investigates whether it results in a smaller effect. The results show two highly significant interaction effects, with coefficients not significantly different from one another, so both forms of philanthropy equally contribute to amplifying the negative effect of CEO overcompensation on media disapproval.

Influence of Sarbanes-Oxley (SOX). In the second half of 2002, the SOX Act introduced new regulations regarding auditing practices, including provisions about executive compensation that could affect our results. We looked at the influence of SOX implementation by adding a dummy variable coded 1 from 2003 onwards. The corresponding coefficient is non-significant in the model testing H1 (model 15), but is positively and significantly $(\beta=0.10 ; p<0.01)$ associated with $C E O$ overcompensation $_{t+1}$ in the model testing $\mathrm{H} 2$, reported as model 16 in Table 4. This finding might signal a substitution effect between transparency and executive compensation, whereby more transparency on executive pay leads firms to feel more comfortable overpaying executives. An alternative explanation comes from structural elaboration theory (Edelman 1992), which proposes that firms "strategically react to regulatory shifts by implementing formal structures that further their own interests, while signaling conformity to institutional expectations” (Joseph et al. 2014: 1836). In 
other words, the passage of SOX could have offered an opportunity for firms to implement self-interested change under the guise of a compliance strategy. In any case, more in-depth analyses in a separate study would be required to fully explain this observation.

\section{DISCUSSION AND CONTRIBUTIONS}

This study began with two related questions which we addressed through the lens of signal incongruence: What drives media disapproval of overpaid CEOs, and when does it trigger cuts in CEO overcompensation? Our study's core finding is the negative impact of signal incongruence on media disapproval, which is both highly significant $(\mathrm{p}<0.001)$ and substantively important (e.g., disapproval of a CEO overcompensated by $\$ 5$ million increases from 13.8 to 37.0 percent when philanthropy increases by one S.D. over its mean). Besides CEO overcompensation itself, we also identified several other factors positively associated with media disapproval (i.e., firm size and media visibility consistently across models; CEO tenure and shareholder activism in some models), as well as several factors negatively associated with disapproval (i.e., philanthropy and shareholder returns consistently across models; founder CEO and firm reputation in some models). Even though our study cannot empirically disentangle stakeholders' various interpretations of signal incongruence (e.g. are top managers being hypocritical or merely hard to read?), both our qualitative and quantitative evidence show that such interpretations are generally negative and reflected in higher levels of media disapproval. It would thus be interesting for future research to delve deeper into the relationship between the nature and diversity of stakeholders' interpretations and the negativity of their social judgments.

Perhaps even more interesting is our contention—supported empirically—-that signal incongruence eventually makes firms more likely to address the cause of the disapproval. Firms engaged in philanthropy receive more disapproval for overcompensating their CEOs (due to signal incongruence), but they also decrease CEO overcompensation more in response to disapproval (to protect or restore their reservoir of goodwill). Indeed, our findings demonstrate that cuts in CEO overcompensation happen, as hypothesized, following periods of media disapproval at firms engaged in philanthropy. They also happen more at older firms, but less at larger, higher-performing firms. Taken together, our findings contribute to theories on signaling (Stern et al. 2014) and infomediaries (Deephouse and Heugens 2009), as well as to the substantive 
literatures on CEO pay (Core et al. 2008), corporate governance (Aguilera et al. 2015, Hsieh et al. 2018, Joe et al. 2009), and firms’ prosocial behavior (Godfrey et al. 2009, Madsen and Rodgers 2015).

\section{Unpacking signal incongruence}

More often than not, firm characteristics are not directly observable, and external stakeholders instead rely on signals to assess them. The crucial role played by these cues in the business world has been examined in many contexts, such as certification (e.g., Sine et al. 2007) and advertising (e.g., Milgrom and Roberts, 1986). However, only recently have the interaction effects between multiple signals attracted scholarly attention. Stern et al. (2014) were the first to theorize about what happens when different signals simultaneously convey information about the same entity. Specifically, they argued and demonstrated empirically that "categorybased processing of congruent signals $[\ldots]$ based on schemas stored in memory $[\ldots]$ leads to predictable judgments" and has a reinforcing effect (Stern et al. 2014: 518; emphasis added).

The present study adds to their work by theorizing about the consequences of signal incongruence, defined as the simultaneous presence of informational cues associated with opposed categories and instilled with conflicting institutional logics. Our findings suggest that these cues are not interpreted in isolation, which casts additional doubt on firms' ability to decouple (visible) activities to improve their image (Bansal and Clelland 2004, Crilly et al. 2012).

While this study was anchored from the start in the CEO compensation literature, future studies could both generalize and refine our theory by examining multiple pairs of congruent and incongruent signals, and by proposing a way to directly measure (in)congruence. For instance, a journalist mentioned the incongruence between a firm's recognition as one of the "best places to work" and the amount of litigation involving female employees. Another example is the potential incongruence between commitment to workplace safety and the amount of product recalls (potentially implying disregard for safety), or between a commitment to cost leadership and excessive managerial perks.

Furthermore, future research could try to unpack how actors justify signal emission and in turn interpret received signals. During an interview, an American journalist (who wishes to remain anonymous) recalled a recent controversy: "Mark Zuckerberg was accused of using philanthropy in 2010 [to raise his 
standing with the media], though I have no idea if the reporting on his motives was accurate". Was Zuckerberg engaging in "decoupling as a form of calculated deception" (Crilly et al. 2012: 1429)—making misleading statements about his good deeds just to hide his profit-motivated agenda? Or was he being genuine, with the perceived hypocrisy residing solely in the eye of the beholder? Indeed, actors constantly face "conflicting stakeholder expectations", which "leads firms to adopt inconsistent standards that they cannot implement simultaneously" (Crilly et al. 2012: 1429). And, since "any actor may be nested in a combination of institutional orders, exposing them to conflicting [...] symbols and practices that are available to reinterpret" (Thornton et al 2015: 2), it is in fact challenging to disentangle signal emitters' true motivations from signal interpreters' own biases. Besides, if all the information about actors' motivations and biases was transparently available to all stakeholders, signaling itself would become self-defeating since there would be no unobservable qualities left requiring the emission of signals. Because of these boundary conditions, scholars should recognize that, in some situations, it may be more realistic to examine the drivers of signal credibility (from the viewpoint of signal interpreters) instead of trying to assess whether signals actually reflect genuine motivations or qualities (since the latter may not be fully known by the signal emitters themselves).

Our study also adds to research on the antecedents of negative evaluations. To explain these antecedents, research so far had drawn attention to the role played by characteristics of the contesting stakeholders (e.g., Rao et al. 2010) and of the contested firms (e.g., Vergne 2012). Our results bridge the two traditions by explaining how cue interpretation by stakeholders affects resulting evaluations. This paves the way for a holistic explanation of firm contestation based on three components: firm characteristics, stakeholder characteristics, and signal interpretation at the interface between firms and their stakeholders.

\section{Infomediaries: Influence, Incentives, and Impact}

The media reflect reality selectively, thereby affecting its perception by audiences (Deephouse and Heugens 2009). Past research has established that firm-supplied information found in press releases has no effect on market outcomes such as IPO underpricing (Pollock and Rindova 2003) because stakeholders deem such information to be biased or not credible. By contrast, our findings show the extent to which, in the context of CEO pay, infomediary-supplied information about firms can affect strategic outcomes, including a firm's 
reputation and CEO compensation policy. This opens up an avenue for future research at the crossroads of the signaling and infomediary literatures. Because journalists gather information about firms to write articles, media signals contribute to the monitoring of firms, but also modify managerial incentives by affecting firm reputation. As such, our findings on media signals suggest that monitoring and incentives are not substitutes_as is sometimes implied by agency theoretic models (e.g., Zajac and Westphal, 1994) — but are in fact closely connected, as showed empirically in the context of board behavior (Rutherford et al 2007).

\section{Corporate governance and CEO pay}

Joe et al. (2009: 581) conjectured that, "by shaming directors and managers, negative media exposure might accomplish what shareholder activism could not", and accordingly found evidence that firms "shamed" in Business Week for having the "worst boards" in America take "steps to improve the quality of their boards following the negative exposure", such as increasing the proportion of external directors (see also Dyck and Zingales 2002). However, in terms of CEO pay, pessimism so far has prevailed. As noted by the business editor of The Economist, "journalism clearly has an ability to influence this debate, not least by shaming people who read the newspapers. But generally I don't think this has been terribly effective” (Bishop et al. 2005: 4). Accordingly, Core et al. (2008: 2) found no evidence "that the press serves as a catalyst or change agent for CEO compensation practices". Bednar (2012: 145) found that "the media can affect CEO dismissal, the makeup of CEO compensation, and the makeup of a board"' (see also Kuhnen and Niessen 2012), but to date, no empirical study has showed that CEO overcompensation could decrease following media criticism.

Our study departs from these past works by revealing a catalytic influence of "shaming" when media disapproval is high at firms engaged in philanthropy (and the media effects that we observe are much more consistent and significant than the effects of shareholder activism). Besides the reputational capital that such firms have to protect (Godfrey 2005), it could also be that these firms are, on average, better governed, and thus more responsive to issues—but more research is needed to investigate this potentially complementary mechanism. In any case, our study adds to research on the negative effects of "unfair" CEO pay (Wade et al. 2006) by showing how philanthropy can contribute to lower(ing) CEO overcompensation. 
Numerous calls have been made to better understand the corporate governance effects of external watchdogs such as the media (Aguilera et al. 2015, Bednar et al. 2013, Hsieh et al. 2018). Our findings demonstrate that, under certain conditions, the media can reshape aspects of firm behavior by enforcing standards of social appropriateness. We thus add to recent research that demonstrates that negative media signals affect the extent of strategic change (Bednar et al. 2013) and can lead to asset divestments (Durand and Vergne 2015) by establishing a connection between media criticism of CEO overcompensation and subsequent remedial actions (i.e., a decrease in CEO overcompensation). As such, our study paves the way for reconnecting the literature on the external constraints imposed by reputation signals (Deephouse 2000, Stern et al. 2014) with impression management research concerned with the internal production of such firm signals (Durand and Vergne 2015, Westphal et al. 2012, Zavyalova et al. 2012).

\section{Reconciling the "insurance" and "bull's eye" views on firms' prosocial behavior?}

An interesting pattern in our findings is the fact that philanthropy, taken in isolation, reduces media disapproval, whereas its interaction with overcompensation increases it (as visible in models 3, 6, and 13-15).

There is an "insurance" view on prosocial behavior which argues that activities such as philanthropy can shield firms from disapproval (Godfrey et al. 2009, Madsen and Rodgers 2015). For instance, Williams and Barrett (2000) find that philanthropy partially shields firms from negative reactions following wrongdoing, because it generates positive moral capital or a "reservoir of goodwill" (Zavyalova et al. 2016) among a firm's audiences (up to a certain point, see Godfrey 2005). Or, as Wang and Qian (2011: 1160) put it, "philanthropy helps firms gain sociopolitical legitimacy, which further enables them to elicit positive stakeholder responses" (or, in our case, to mitigate negative media coverage). This view is reflected in our finding that philanthropy's main effect on media disapproval is negative and highly significant across models.

But other researchers argue that "engaging in reputation-building actions, like announcing prosocial activities, exposes a firm to activist attention", and as such, "scholars who have asserted that [...] reputationbuilding activities have insurance-like properties that protect a firm from future activist challenges may be partially wrong" (King and McDonnell 2015: 448). King and McDonnell note that activists may be more inclined to boycott firms that do good deeds for two reasons. First, such firms tend to be highly visible 
because of their community involvement, and activists can benefit from this visibility by targeting them (resulting in more negative media coverage). Second, by targeting firms already committed to community involvement, activists put these firms in a position where they must react, either by yielding to their demands or by further increasing their community involvement to maintain their reputation. Thus, far from shielding firms from further social sanctions, prosocial activities such as philanthropy may in fact place the firm into the bull's eye of critics' target. While, to our knowledge, these ideas have never been formally stated as hypotheses and tested on large samples, they certainly have merit—in fact, in our models, the positive sign on the interaction between philanthropy and overcompensation lends support to this alternative view.

Thus, our study paves the way for a reconciliation of the "insurance" (Godfrey 2005) and "bull's eye" views (King and McDonnell 2015) based on insights from the infomediary and signaling literatures. In our results, the insurance view manifests itself as the main, negative effect of philanthropy on disapproval, whereas the bull's eye effect kicks in when signal incongruence raises media suspicion regarding the firm's behavior and values. Importantly, our theory contributes to explaining how the two effects can coexist, thereby bridging, for the first time, two (seemingly) opposing perspectives. Interestingly, Figure 2 above clearly depicts the coexistence of the two effects, with the insurance effect prevailing only in the darker area located below zero on the vertical axis (i.e., for high values of philanthropy and low overcompensation).

As a final remark, we note an interesting contrast between media and scholarly accounts regarding societal issues such as CEO pay. While the media tend to focus on outlying cases to raise awareness about issues (e.g., by picking “scapegoats"), scholars seek to understand average trends, often at the expense of clear-cut, definitive answers - at times leaving some observers with the impression that the media are in fact better equipped to rapidly focus public attention and shape societal debates. As scholars who occasionally appear in the media, we would like to emphasize the complementarities between media and scholarly accounts—which this study illustrates (but see Watts and Rothschild 2017 for a less optimistic view). Especially these days, with the advent of systematic "fact checking" and "data journalism", we feel the urge to call for a deeper reflection on the untapped opportunities to cross-fertilize the academic and media spheres, so that we can maximize the positive impact of our respective contributions on society. 
Figure 1: Media attention to CEO compensation and philanthropy

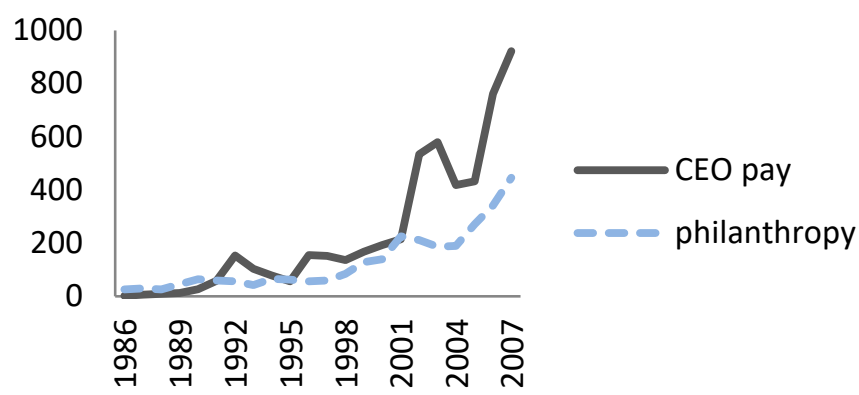

Note. The Y axis indicates how many articles in major U.S. media contain [CEO pay or compensation], and [corporate philanthropy].

\section{Figure 2: Philanthropy moderates the overcompensation-disapproval relationship}

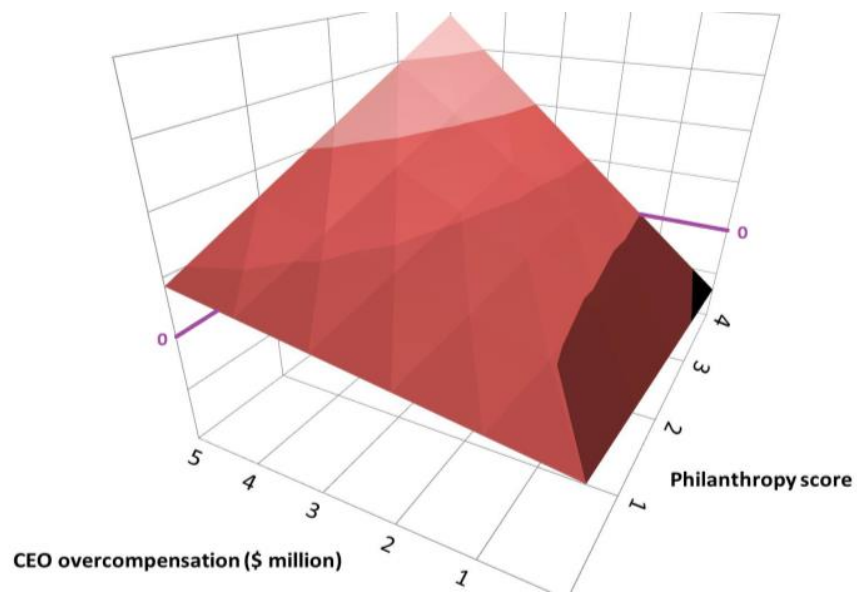

Note. The vertical axis reflects the joint impact of CEO overcompensation and philanthropy (calculated from Model 6's main \& interaction effects) on the log-odds of media disapproval. The darker area is located below 0 , indicating a decrease in log-odds (in our sample, this is the case for $40.5 \%$ of firm-year observations; $74.2 \%$ of firms have at least one yearly observation in the darker area).

Figure 3: Marginal effect of media disapproval $(\mathrm{t})$ on CEO overcompensation $(\mathrm{t}+1)$

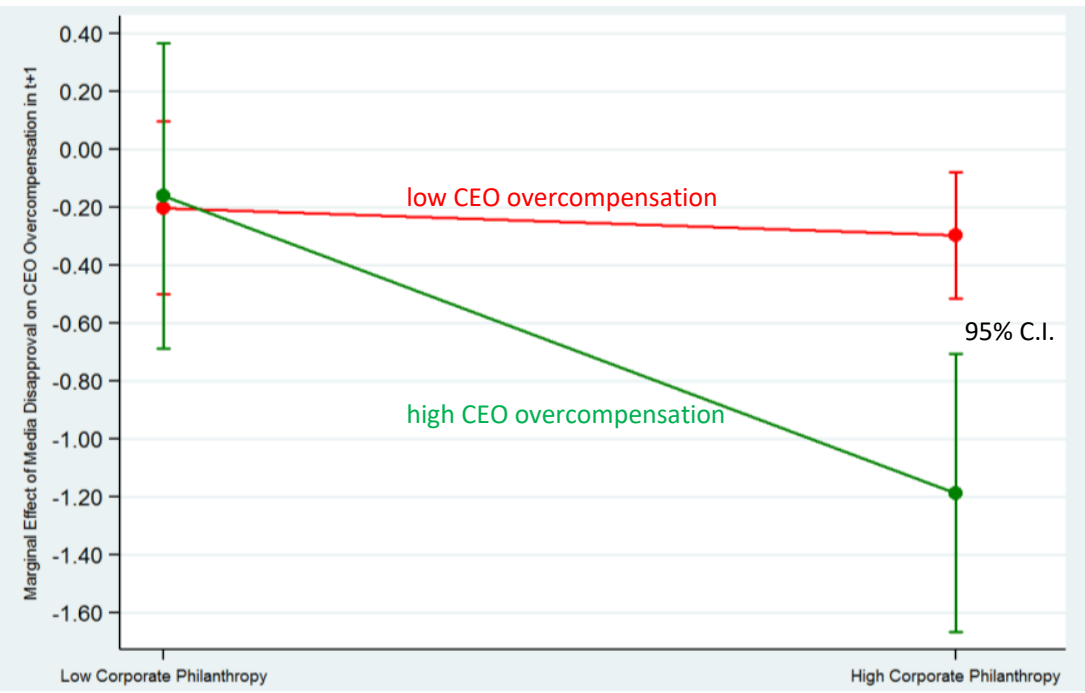

Note. In line with H2, the marginal effect of disapproval is increasingly negative as philanthropy and overcompensation become larger. At low levels of philanthropy, the sizes of the marginal effects of disapproval for high and low compensation are statistically indistinguishable from each other, as is visible from their similar point estimates (around -0.20) and overlapping confidence intervals. 
Table 1. Summary statistics and correlation matrix

\begin{tabular}{|c|c|c|c|c|c|c|c|c|c|c|c|c|c|c|c|c|c|c|}
\hline & Variable & Mean & S.D. & Min & Max & (1) & (2) & (3) & (4) & (5) & (6) & (7) & (8) & (9) & (10) & (11) & (12) & (13) \\
\hline (1) & Media disapproval (ratio) & 0.11 & 0.27 & 0.00 & 1.00 & & & & & & & & & & & & & \\
\hline (2) & Media disapproval (count) & 0.52 & 1.82 & 0.00 & 58.00 & 0.57 & & & & & & & & & & & & \\
\hline (3) & Philanthropy & 0.84 & 1.02 & 0.00 & 4.00 & -0.18 & -0.10 & & & & & & & & & & & \\
\hline (4) & CEO overcompensation $(t+1)$ & -0.03 & 0.90 & -9.50 & 4.41 & 0.13 & 0.03 & -0.17 & & & & & & & & & & \\
\hline (5) & CEO overcompensation & -0.04 & 0.94 & -9.50 & 4.47 & 0.33 & 0.17 & -0.29 & 0.59 & & & & & & & & & \\
\hline (6) & Firm size & 8.28 & 1.67 & 2.52 & 14.62 & 0.16 & 0.20 & 0.12 & 0.11 & 0.09 & & & & & & & & \\
\hline (7) & Firm age & 3.66 & 0.48 & 2.30 & 4.33 & 0.00 & 0.04 & 0.14 & -0.05 & -0.06 & 0.38 & & & & & & & \\
\hline (8) & Fortune most admired & 0.29 & 0.45 & 0.00 & 1.00 & 0.08 & 0.13 & 0.06 & -0.00 & 0.01 & 0.46 & 0.32 & & & & & & \\
\hline (9) & Media visibility & 2.56 & 1.63 & 0.00 & 8.62 & 0.13 & 0.18 & 0.04 & 0.06 & 0.07 & 0.47 & 0.21 & 0.33 & & & & & \\
\hline (10) & Number of analysts following & 3.21 & 0.88 & 0.00 & 5.30 & 0.18 & 0.16 & -0.01 & 0.13 & 0.16 & 0.44 & 0.04 & 0.29 & 0.29 & & & & \\
\hline (11) & Shareholder returns & 0.20 & 0.40 & -0.83 & 2.05 & -0.06 & -0.04 & 0.01 & 0.00 & -0.02 & -0.07 & -0.07 & -0.01 & -0.01 & -0.07 & & & \\
\hline (12) & Return on assets & 0.06 & 0.07 & -0.32 & 0.27 & -0.03 & -0.03 & 0.01 & 0.02 & -0.01 & -0.13 & 0.00 & 0.03 & -0.03 & 0.04 & 0.16 & & \\
\hline (13) & Concerns "philanthropy" & 0.10 & 0.33 & 0.00 & 3.00 & 0.06 & 0.08 & 0.07 & -0.00 & -0.00 & 0.35 & 0.18 & 0.14 & 0.23 & 0.12 & -0.03 & -0.07 & \\
\hline (14) & Shareholder activism & 0.29 & 0.54 & 0.00 & 3.30 & 0.11 & 0.19 & 0.11 & -0.01 & -0.00 & 0.50 & 0.31 & 0.37 & 0.43 & 0.25 & -0.04 & -0.01 & 0.28 \\
\hline (15) & CEO tenure & 1.62 & 0.91 & 0.00 & 4.01 & 0.04 & 0.05 & -0.04 & 0.02 & 0.01 & -0.05 & -0.08 & -0.05 & -0.06 & 0.01 & 0.01 & 0.05 & -0.04 \\
\hline (16) & Founder CEO & 0.04 & 0.20 & 0.00 & 1.00 & -0.01 & -0.01 & -0.01 & -0.07 & -0.07 & -0.10 & -0.15 & -0.04 & -0.05 & 0.00 & 0.01 & 0.02 & -0.05 \\
\hline (17) & Female CEO & 0.02 & 0.13 & 0.00 & 1.00 & -0.01 & 0.00 & -0.00 & 0.01 & 0.01 & -0.06 & -0.04 & -0.03 & -0.01 & -0.02 & 0.00 & 0.01 & -0.02 \\
\hline (18) & $\mathrm{CEO} /$ Chairman duality & 0.66 & 0.48 & 0.00 & 1.00 & 0.04 & 0.06 & 0.03 & 0.07 & 0.06 & 0.20 & 0.19 & 0.13 & 0.08 & 0.11 & -0.03 & -0.01 & 0.08 \\
\hline (19) & Anticipated CEO compensation & 8.21 & 0.67 & 5.44 & 10.87 & 0.07 & 0.14 & 0.15 & 0.01 & -0.06 & 0.76 & 0.39 & 0.51 & 0.47 & 0.40 & 0.03 & 0.13 & 0.27 \\
\hline (20) & $\%$ Votes Democrats & 50.39 & 7.47 & 26.00 & 89.18 & 0.05 & 0.04 & 0.02 & 0.10 & 0.10 & 0.06 & 0.04 & 0.04 & 0.01 & 0.02 & 0.00 & -0.02 & -0.03 \\
\hline (21) & Mean philanthropy (industry) & 0.23 & 0.24 & 0.00 & 1.67 & 0.04 & 0.04 & 0.19 & 0.00 & 0.01 & 0.28 & 0.19 & 0.08 & -0.02 & 0.13 & -0.00 & -0.03 & 0.10 \\
\hline (22) & Number of media directors & 0.33 & 0.47 & 0.00 & 1.00 & 0.07 & 0.10 & 0.05 & 0.02 & 0.03 & 0.27 & 0.16 & 0.18 & 0.20 & 0.16 & -0.02 & -0.00 & 0.04 \\
\hline (23) & Share volatility & 43.51 & 395.4 & 0.98 & 12100.3 & 0.03 & 0.01 & 0.04 & 0.03 & 0.03 & 0.08 & 0.07 & 0.06 & 0.03 & 0.04 & -0.02 & 0.03 & -0.01 \\
\hline (24) & Elite college education & 0.29 & 0.46 & 0.00 & 1.00 & 0.08 & 0.04 & 0.04 & 0.06 & 0.06 & 0.18 & 0.14 & 0.10 & 0.08 & 0.09 & 0.01 & 0.02 & -0.01 \\
\hline (25) & Number of children & 1.83 & 1.63 & 0.00 & 13.00 & 0.07 & 0.08 & 0.03 & 0.04 & 0.04 & 0.22 & 0.18 & 0.17 & 0.12 & 0.11 & -0.01 & 0.03 & 0.05 \\
\hline (26) & Number of boys & 0.72 & 1.01 & 0.00 & 9.00 & 0.04 & 0.06 & 0.06 & 0.00 & -0.00 & 0.14 & 0.11 & 0.08 & 0.07 & 0.07 & -0.01 & 0.02 & 0.00 \\
\hline (27) & Mean CEO overpay (industry) & -0.00 & 0.06 & -0.81 & 1.01 & -0.09 & -0.06 & 0.06 & -0.21 & -0.22 & -0.08 & -0.01 & -0.02 & -0.03 & -0.07 & 0.01 & -0.00 & -0.02 \\
\hline (28) & Sarbanes-Oxley (SOX) & 0.59 & 0.49 & 0.00 & 1.00 & -0.02 & -0.01 & -0.10 & 0.02 & 0.01 & -0.15 & -0.27 & -0.12 & 0.18 & -0.19 & 0.16 & -0.00 & 0.00 \\
\hline
\end{tabular}




\section{Table 1. (continued)}

\begin{tabular}{|c|c|c|c|c|c|c|c|c|c|c|c|c|c|c|c|c|c|c|c|}
\hline & Variable & Mean & S.D. & Min & Max & (14) & (15) & (16) & $(17)$ & (18) & (19) & $(20)$ & (21) & $(22)$ & (23) & (24) & (25) & (26) & (27) \\
\hline (15) & CEO tenure & 1.62 & 0.91 & 0.00 & 4.01 & -0.09 & & & & & & & & & & & & & \\
\hline (16) & Founder CEO & 0.04 & 0.20 & 0.00 & 1.00 & -0.06 & 0.37 & & & & & & & & & & & & \\
\hline (17) & Female CEO & 0.02 & 0.13 & 0.00 & 1.00 & -0.01 & -0.04 & 0.02 & & & & & & & & & & & \\
\hline (18) & $\mathrm{CEO} /$ Chairman duality & 0.66 & 0.48 & 0.00 & 1.00 & 0.11 & 0.31 & 0.07 & -0.04 & & & & & & & & & & \\
\hline (19) & Anticipated CEO compensation & 8.21 & 0.67 & 5.44 & 10.87 & 0.52 & -0.05 & -0.08 & -0.05 & 0.18 & & & & & & & & & \\
\hline (20) & $\%$ Votes Democrats & 50.39 & 7.47 & 26.00 & 89.18 & 0.03 & 0.02 & 0.03 & 0.03 & 0.01 & 0.02 & & & & & & & & \\
\hline (21) & Mean philanthropy (industry) & 0.23 & 0.24 & 0.00 & 1.67 & 0.08 & -0.01 & -0.02 & 0.00 & 0.13 & 0.10 & 0.10 & & & & & & & \\
\hline (22) & Number of media directors & 0.33 & 0.47 & 0.00 & 1.00 & 0.21 & -0.06 & -0.05 & 0.03 & 0.05 & 0.26 & 0.11 & 0.12 & & & & & & \\
\hline (23) & Share volatility & 43.51 & 395.4 & 0.98 & 12100.3 & 0.08 & -0.01 & -0.01 & -0.01 & 0.03 & 0.08 & 0.05 & 0.03 & 0.05 & & & & & \\
\hline (24) & Elite college education & 0.29 & 0.46 & 0.00 & 1.00 & 0.10 & 0.06 & -0.02 & -0.01 & 0.09 & 0.16 & 0.17 & 0.11 & 0.11 & 0.07 & & & & \\
\hline (25) & Number of children & 1.83 & 1.63 & 0.00 & 13.00 & 0.13 & 0.11 & 0.03 & -0.03 & 0.14 & 0.20 & 0.03 & 0.13 & 0.11 & 0.04 & 0.12 & & & \\
\hline (26) & Number of boys & 0.72 & 1.01 & 0.00 & 9.00 & 0.07 & 0.17 & 0.08 & 0.00 & 0.12 & 0.11 & 0.03 & 0.13 & 0.04 & 0.03 & 0.10 & 0.56 & & \\
\hline (27) & Mean CEO overpay (industry) & 0.00 & 0.06 & -0.81 & 1.01 & -0.02 & -0.03 & 0.06 & -0.01 & -0.05 & -0.05 & -0.02 & -0.01 & -0.02 & -0.00 & -0.02 & -0.02 & -0.01 & \\
\hline (28) & Sarbanes-Oxley (SOX) & 0.59 & 0.49 & 0.00 & 1.00 & -0.01 & 0.01 & 0.01 & 0.02 & -0.17 & -0.11 & -0.08 & -0.45 & -0.11 & -0.04 & -0.11 & -0.15 & -0.14 & 0.02 \\
\hline
\end{tabular}

Note: Media visibility, number of analysts, size, age, CEO tenure, shareholder activism, and compensation variables are logged. 
Table 2. Testing Hypothesis 1 (Dependent variable: Media disapproval)

\begin{tabular}{|c|c|c|c|c|c|c|}
\hline & $\begin{array}{l}\text { (1) probit } \\
1 \text { if overcom- } \\
\text { pensation }\end{array}$ & $\begin{array}{l}\text { (2) baseline } H \\
\text { disapproval } \\
(\text { GLM) }\end{array}$ & $\begin{array}{l}\text { (3) H1 test } \\
\text { disapproval } \\
\text { (GLM) }\end{array}$ & $\begin{array}{l}\text { (4) probit } \\
1 \text { if phil- } \\
\text { anthropy }\end{array}$ & $\begin{array}{l}\text { (5) baseline } H \\
\text { disapproval } \\
\text { (GLM) }\end{array}$ & $\begin{array}{l}\text { (6) H1 test } \\
\text { disapproval } \\
(\mathrm{GLM})\end{array}$ \\
\hline $\begin{array}{l}\text { Philanthropy x CEO overcomp- } \\
\text { ensation }\end{array}$ & & & $\begin{array}{l}1.45 * * * \\
(0.17)\end{array}$ & & & $\begin{array}{l}1.54 * * * \\
(0.18)\end{array}$ \\
\hline CEO overcompensation & & $\begin{array}{l}0.96 * * * \\
(0.10)\end{array}$ & $\begin{array}{l}1.88 * * * \\
(0.13)\end{array}$ & $\begin{array}{l}-0.51 * * * \\
(0.02)\end{array}$ & $\begin{array}{l}0.70 * \\
(0.36)\end{array}$ & $\begin{array}{l}1.26 * * * \\
(0.22)\end{array}$ \\
\hline Philanthropy & $\begin{array}{l}-0.40 * * * \\
(0.02)\end{array}$ & $\begin{array}{l}-0.22+ \\
(0.13)\end{array}$ & $\begin{array}{l}-0.68^{* * *} \\
(0.15)\end{array}$ & & $\begin{array}{l}-0.35^{* * * *} \\
(0.09)\end{array}$ & $\begin{array}{l}-0.69 * * * \\
(0.12)\end{array}$ \\
\hline Anticipated CEO compensation & $\begin{array}{l}-0.76^{* * *} \\
(0.05)\end{array}$ & $\begin{array}{l}0.09 \\
(0.18)\end{array}$ & $\begin{array}{l}-0.13 \\
(0.18)\end{array}$ & $\begin{array}{l}0.23 * * * \\
(0.05)\end{array}$ & $\begin{array}{l}0.01 \\
(0.14)\end{array}$ & $\begin{array}{l}0.14 \\
(0.13)\end{array}$ \\
\hline Firm size & $\begin{array}{l}0.34 * * * \\
(0.02)\end{array}$ & $\begin{array}{l}0.10 \\
(0.08)\end{array}$ & $\begin{array}{l}0.14+ \\
(0.08)\end{array}$ & $\begin{array}{l}0.01 \\
(0.02)\end{array}$ & $\begin{array}{l}0.21 * * * \\
(0.06)\end{array}$ & $\begin{array}{l}0.20 * * * \\
(0.06)\end{array}$ \\
\hline Firm age & $\begin{array}{l}-0.09 * \\
(0.04)\end{array}$ & $\begin{array}{l}0.06 \\
(0.10)\end{array}$ & $\begin{array}{l}0.05 \\
(0.09)\end{array}$ & $\begin{array}{l}0.06 \\
(0.04)\end{array}$ & $\begin{array}{l}0.07 \\
(0.10)\end{array}$ & $\begin{array}{l}0.12 \\
(0.10)\end{array}$ \\
\hline Fortune most admired & $\begin{array}{l}-0.04 \\
(0.04)\end{array}$ & $\begin{array}{l}0.00 \\
(0.09)\end{array}$ & $\begin{array}{l}0.02 \\
(0.09)\end{array}$ & $\begin{array}{l}-0.07 \\
(0.04)\end{array}$ & $\begin{array}{l}-0.07 \\
(0.11)\end{array}$ & $\begin{array}{l}-0.11 \\
(0.10)\end{array}$ \\
\hline Media visibility & $\begin{array}{l}0.05^{* * *} \\
(0.01)\end{array}$ & $\begin{array}{l}0.05 \\
(0.03)\end{array}$ & $\begin{array}{l}0.07 * \\
(0.03)\end{array}$ & $\begin{array}{l}-0.00 \\
(0.01)\end{array}$ & $\begin{array}{l}0.06^{*} \\
(0.03)\end{array}$ & $\begin{array}{l}0.06^{*} \\
(0.03)\end{array}$ \\
\hline Concerns "philanthropy" & $\begin{array}{l}-0.13^{*} \\
(0.05)\end{array}$ & $\begin{array}{l}0.12 \\
(0.11)\end{array}$ & $\begin{array}{l}0.07 \\
(0.11)\end{array}$ & $\begin{array}{l}-0.02 \\
(0.05)\end{array}$ & $\begin{array}{l}0.05 \\
(0.11)\end{array}$ & $\begin{array}{l}0.01 \\
(0.11)\end{array}$ \\
\hline Shareholder returns & $\begin{array}{l}0.10^{*} \\
(0.04)\end{array}$ & $\begin{array}{l}-0.27^{* *} \\
(0.10)\end{array}$ & $\begin{array}{l}-0.23^{*} \\
(0.10)\end{array}$ & $\begin{array}{l}0.02 \\
(0.04)\end{array}$ & $\begin{array}{c}-0.23^{*} \\
(0.10)\end{array}$ & $\begin{array}{l}-0.20^{*} \\
(0.10)\end{array}$ \\
\hline Return on assets & $\begin{array}{l}1.83^{* * *} \\
(0.23)\end{array}$ & $\begin{array}{l}-0.48 \\
(0.66)\end{array}$ & $\begin{array}{l}-0.12 \\
(0.63)\end{array}$ & $\begin{array}{l}-0.01 \\
(0.23)\end{array}$ & $\begin{array}{l}0.12 \\
(0.54)\end{array}$ & $\begin{array}{l}0.09 \\
(0.51)\end{array}$ \\
\hline $\mathrm{CEO} /$ Chairman duality & $\begin{array}{l}0.16^{* * *} \\
(0.04)\end{array}$ & $\begin{array}{l}-0.10 \\
(0.09)\end{array}$ & $\begin{array}{l}-0.10 \\
(0.09)\end{array}$ & $\begin{array}{l}0.00 \\
(0.03)\end{array}$ & $\begin{array}{l}-0.05 \\
(0.08)\end{array}$ & $\begin{array}{l}-0.07 \\
(0.08)\end{array}$ \\
\hline $\mathrm{CEO}$ tenure & $\begin{array}{l}0.02 \\
(0.02)\end{array}$ & $\begin{array}{l}0.11^{* *} \\
(0.04)\end{array}$ & $\begin{array}{l}0.13^{* *} \\
(0.04)\end{array}$ & $\begin{array}{l}-0.04 * \\
(0.02)\end{array}$ & $\begin{array}{l}0.10^{*} \\
(0.05)\end{array}$ & $\begin{array}{l}0.08 \\
(0.04)\end{array}$ \\
\hline Founder CEO & $\begin{array}{l}-0.31^{* * *} \\
(0.08)\end{array}$ & $\begin{array}{l}0.03 \\
(0.19)\end{array}$ & $\begin{array}{l}0.01 \\
(0.19)\end{array}$ & $\begin{array}{l}-0.05 \\
(0.08)\end{array}$ & $\begin{array}{l}-0.10 \\
(0.19)\end{array}$ & $\begin{array}{l}-0.09 \\
(0.19)\end{array}$ \\
\hline Female CEO & $\begin{array}{l}0.27 * \\
(0.12)\end{array}$ & $\begin{array}{l}-0.46 \\
(0.30)\end{array}$ & $\begin{array}{l}-0.48^{*} \\
(0.24)\end{array}$ & $\begin{array}{l}-0.00 \\
(0.12)\end{array}$ & $\begin{array}{l}-0.38 \\
(0.31)\end{array}$ & $\begin{array}{l}-0.44 \\
(0.25)\end{array}$ \\
\hline Shareholder activism & $\begin{array}{l}0.02 \\
(0.04)\end{array}$ & $\begin{array}{l}0.15^{*} \\
(0.07)\end{array}$ & $\begin{array}{l}0.16^{*} \\
(0.07)\end{array}$ & $\begin{array}{l}-0.04 \\
(0.04)\end{array}$ & $\begin{array}{l}0.14 \\
(0.08)\end{array}$ & $\begin{array}{l}0.11 \\
(0.07)\end{array}$ \\
\hline Number of analysts following & $\begin{array}{l}0.18^{* * *} \\
(0.02)\end{array}$ & $\begin{array}{l}0.21^{* *} \\
(0.06)\end{array}$ & $\begin{array}{l}0.25^{* * *} \\
(0.07)\end{array}$ & $\begin{array}{l}-0.10^{* * *} \\
(0.02)\end{array}$ & $\begin{array}{l}0.20^{*} \\
(0.08)\end{array}$ & $\begin{array}{l}0.10 \\
(0.07)\end{array}$ \\
\hline$\%$ Votes Democrat & & & & $\begin{array}{l}0.00^{*} \\
(0.00)\end{array}$ & & \\
\hline Mean philanthropy (industry) & & & & $\begin{array}{l}0.65^{* * *} \\
(0.08)\end{array}$ & & \\
\hline Mean CEO overpay (industry) & $\begin{array}{l}-3.58^{* * *} \\
(0.30)\end{array}$ & & & & & \\
\hline Share volatility & $\begin{array}{l}0.00^{* * *} \\
(0.00)\end{array}$ & & & & & \\
\hline Elite college education & $0.15^{* * *}$ & & & & & \\
\hline
\end{tabular}




\begin{tabular}{|c|c|c|c|c|c|c|}
\hline \multirow{3}{*}{ Number of children } & $(0.03)$ & & & & & \\
\hline & $0.03 *$ & & & & & \\
\hline & $(0.01)$ & & & & & \\
\hline \multirow[t]{2}{*}{ Number of boys } & $-0.04 *$ & & & & & \\
\hline & $(0.02)$ & & & & & \\
\hline Inverse Mills ratio & & $\begin{array}{l}-0.55 \\
(0.38)\end{array}$ & $\begin{array}{l}-0.08 \\
(0.37)\end{array}$ & & $\begin{array}{l}0.77 \\
(0.79)\end{array}$ & $\begin{array}{l}1.94 * * * \\
(0.55)\end{array}$ \\
\hline Constant & $\begin{array}{l}2.72^{* * *} \\
(0.31)\end{array}$ & $\begin{array}{l}-4.91 * * * \\
(0.77)\end{array}$ & $\begin{array}{l}-4.19^{* * *} \\
(0.76)\end{array}$ & $\begin{array}{l}-1.96^{* * *} \\
(0.32)\end{array}$ & $\begin{array}{l}-6.34 * * * \\
(1.52)\end{array}$ & $\begin{array}{l}-8.12^{* * *} \\
(1.20)\end{array}$ \\
\hline Year dummies & Incl. & Incl. & Incl. & Incl. & Incl. & Incl. \\
\hline Industry dummies & Incl. & Incl. & Incl. & Incl. & Incl. & Incl. \\
\hline Number of observations & 8004 & 8004 & 8004 & 8004 & 8004 & 8004 \\
\hline (Pseudo) R-Squared & 0.12 & 0.20 & 0.23 & 0.12 & 0.19 & 0.23 \\
\hline
\end{tabular}

Note. Standard errors are shown in parentheses. ${ }^{*} p<0.05,{ }^{* *} p<0.01,{ }^{* * *} p<0.001$

Table 3. Testing Hypothesis 2

\begin{tabular}{|c|c|c|c|c|c|}
\hline & $\begin{array}{l}\text { (7) } 2 S L S \\
\text { regression }\end{array}$ & $\begin{array}{l}\text { (8) Probit } \\
\text { selection } \\
\text { model }\end{array}$ & $\begin{array}{l}\text { (9) Control } \\
\text { model }\end{array}$ & $\begin{array}{l}\text { (10) Two-way } \\
\text { interactions }\end{array}$ & (11) H2 test \\
\hline & $\begin{array}{l}\text { DV: CEO } \\
\text { overcomp }_{(t+1)}\end{array}$ & $\begin{array}{l}\text { DV: } \\
\text { disapproval }\end{array}$ & $\begin{array}{l}\text { DV: CEO } \\
\text { overcomp }_{(t+1)}\end{array}$ & $\begin{array}{l}\text { DV: } \text { CEO } \\
\text { overcomp }_{(t+1)}\end{array}$ & $\begin{array}{l}\text { DV: } \mathrm{CEO} \\
\text { overcomp }_{(\mathrm{t}+1)}\end{array}$ \\
\hline Media disapproval (instrumented) ${ }^{1}$ & $\begin{array}{l}-0.72 * * \\
(0.27)\end{array}$ & & & & \\
\hline Overcomp. $*$ disapproval $*$ philanthropy & & & & & $\begin{array}{l}-0.24 * \\
(0.11)\end{array}$ \\
\hline Philanthropy & $\begin{array}{l}-0.03^{*} \\
(0.01)\end{array}$ & $\begin{array}{l}-0.46^{* * *} \\
(0.03)\end{array}$ & $\begin{array}{l}-0.27 * \\
(0.11)\end{array}$ & $\begin{array}{l}-0.22^{*} \\
(0.10)\end{array}$ & $\begin{array}{l}-0.19+ \\
(0.10)\end{array}$ \\
\hline CEO overcompensation & $\begin{array}{l}0.61 * * * \\
(0.03)\end{array}$ & $\begin{array}{l}0.49 * * * \\
(0.03)\end{array}$ & $\begin{array}{l}0.38^{*} \\
(0.16)\end{array}$ & $\begin{array}{l}0.29 * * \\
(0.09)\end{array}$ & $\begin{array}{l}0.27 * * \\
(0.09)\end{array}$ \\
\hline Media disapproval & & & $\begin{array}{l}-0.30^{* * *} \\
(0.06)\end{array}$ & $\begin{array}{l}-0.32^{*} \\
(0.13)\end{array}$ & $\begin{array}{l}-0.24^{*} \\
(0.11)\end{array}$ \\
\hline CEO overcompensation $*$ disapproval & & & & $\begin{array}{l}-0.03 \\
(0.19)\end{array}$ & $\begin{array}{l}-0.18 \\
(0.15)\end{array}$ \\
\hline CEO overcompensation * philanthropy & & & & $\begin{array}{l}-0.05 \\
(0.05)\end{array}$ & $\begin{array}{l}-0.06 \\
(0.05)\end{array}$ \\
\hline Media disapproval $*$ philanthropy & & & & $\begin{array}{l}-0.16^{* *} \\
(0.06)\end{array}$ & $\begin{array}{l}-0.05 \\
(0.08)\end{array}$ \\
\hline Anticipated CEO compensation & $\begin{array}{l}0.06+ \\
(0.03)\end{array}$ & $\begin{array}{l}-0.24^{* * *} \\
(0.07)\end{array}$ & $\begin{array}{l}-0.11 \\
(0.10)\end{array}$ & $\begin{array}{l}-0.08 \\
(0.12)\end{array}$ & $\begin{array}{l}-0.08 \\
(0.12)\end{array}$ \\
\hline Firm size & $\begin{array}{l}0.06^{* * *} \\
(0.01)\end{array}$ & $\begin{array}{l}0.20^{* * *} \\
(0.03)\end{array}$ & $\begin{array}{l}0.38^{* * *} \\
(0.06)\end{array}$ & $\begin{array}{l}0.34^{* * *} \\
(0.06)\end{array}$ & $\begin{array}{l}0.34^{* * *} \\
(0.06)\end{array}$ \\
\hline Firm age & $\begin{array}{l}-0.06^{*} \\
(0.02)\end{array}$ & $\begin{array}{l}-0.02 \\
(0.06)\end{array}$ & $\begin{array}{l}-1.87 * * * \\
(0.42)\end{array}$ & $\begin{array}{l}-1.82^{* * *} \\
(0.42)\end{array}$ & $\begin{array}{l}-1.84^{* * *} \\
(0.42)\end{array}$ \\
\hline Fortune most admired & $-0.08^{* *}$ & 0.04 & 0.02 & 0.01 & 0.01 \\
\hline
\end{tabular}




\begin{tabular}{|c|c|c|c|c|c|}
\hline & $(0.03)$ & $(0.06)$ & $(0.03)$ & $(0.03)$ & $(0.03)$ \\
\hline \multirow[t]{2}{*}{ Media visibility } & 0.01 & $0.08^{* * *}$ & 0.03 & 0.01 & 0.01 \\
\hline & $(0.01)$ & $(0.02)$ & $(0.02)$ & $(0.03)$ & $(0.03)$ \\
\hline \multirow[t]{2}{*}{ Concerns "philanthropy" } & -0.04 & -0.05 & -0.02 & -0.01 & -0.00 \\
\hline & $(0.03)$ & $(0.07)$ & $(0.03)$ & $(0.04)$ & $(0.04)$ \\
\hline \multirow[t]{2}{*}{ Shareholder returns } & 0.01 & $-0.12+$ & -0.09 & -0.06 & -0.06 \\
\hline & $(0.03)$ & $(0.06)$ & $(0.06)$ & $(0.05)$ & $(0.05)$ \\
\hline \multirow[t]{2}{*}{ Return on assets } & $0.39 * *$ & -0.21 & $0.65^{*}$ & $0.69^{*}$ & $0.67 *$ \\
\hline & $(0.14)$ & $(0.33)$ & $(0.30)$ & $(0.27)$ & $(0.27)$ \\
\hline \multirow[t]{2}{*}{ CEO/Chairman duality } & $0.05^{*}$ & -0.06 & 0.00 & 0.01 & 0.01 \\
\hline & $(0.02)$ & $(0.05)$ & $(0.04)$ & $(0.04)$ & $(0.04)$ \\
\hline \multirow[t]{2}{*}{ CEO tenure } & 0.02 & $0.09^{* * *}$ & $0.05^{*}$ & 0.04 & 0.04 \\
\hline & $(0.01)$ & $(0.03)$ & $(0.03)$ & $(0.03)$ & $(0.03)$ \\
\hline \multirow[t]{2}{*}{ Founder CEO } & $-0.12 *$ & -0.11 & -0.26 & -0.24 & -0.23 \\
\hline & $(0.05)$ & $(0.12)$ & $(0.20)$ & $(0.21)$ & $(0.21)$ \\
\hline \multirow[t]{2}{*}{ Female CEO } & 0.03 & -0.06 & -0.00 & -0.00 & 0.00 \\
\hline & $(0.07)$ & $(0.18)$ & $(0.13)$ & $(0.13)$ & $(0.13)$ \\
\hline \multirow[t]{2}{*}{ Shareholder activism } & $-0.05^{*}$ & $0.28^{* * *}$ & 0.07 & 0.04 & 0.03 \\
\hline & $(0.02)$ & $(0.05)$ & $(0.07)$ & $(0.06)$ & $(0.06)$ \\
\hline \multirow[t]{2}{*}{ Number of analysts following } & & $0.15^{* * *}$ & & & \\
\hline & & $(0.03)$ & & & \\
\hline \multirow[t]{2}{*}{ Media director } & & $0.12 *$ & & & \\
\hline & & $(0.05)$ & & & \\
\hline \multirow[t]{2}{*}{ Mean distance firm-media HQs } & & $0.00^{* * *}$ & & & \\
\hline & & $(0.00)$ & & & \\
\hline \multirow[t]{2}{*}{ Inverse Mills ratio } & & & $0.65^{*}$ & $0.46+$ & $0.44+$ \\
\hline & & & $(0.30)$ & $(0.25)$ & $(0.25)$ \\
\hline \multirow[t]{2}{*}{ Constant } & $-0.86^{* * *}$ & $2.88^{* *}$ & $3.43+$ & $3.66^{*}$ & $3.76^{*}$ \\
\hline & $(0.18)$ & $(0.42)$ & $(1.93)$ & $(1.83)$ & $(1.82)$ \\
\hline Year dummies & Incl. & & Incl. & Incl. & Incl. \\
\hline Industry dummies & Incl. & & & & \\
\hline Firm fixed-effects & & & Incl. & Incl. & Incl. \\
\hline Number of observations & 6225 & 6225 & 6225 & 6225 & 6225 \\
\hline Centered $\mathrm{R}^{2}$ (pseudo $\mathrm{R}^{2}$, adjusted $\mathbf{R}^{2}$ ) & 0.37 & 0.29 & 0.053 & 0.062 & 0.065 \\
\hline
\end{tabular}

Note. Standard errors are shown in parentheses. ${ }^{*} p<0.05,{ }^{* *} p<0.01,{ }^{* * *} p<0.001$

${ }^{1}$ Media disapproval was instrumented using three variables: A dummy equal to 1 if the firm's board includes a media director; the number of analysts following the firm; the median distance between the location of a firm's headquarters (HQs) and the HQs of all media organizations that provided media articles during our observations period. Together these instruments are strong $(\mathrm{F}$ statistic $=33.39, \mathrm{p}=0.00)$ and pass the exogeneity tests recommended by Bascle $(2008)$, taken together $(\mathrm{p}=0.22)$ as well as taken separately (all three p-values $>0.10$ ). Specifically, we computed the F-, Hansen's J-, Basmann, and difference-in-Sargan statistics. Model 7 computes standard errors robust to both heteroscedasticity and autocorrelation. 
Table 4. Robustness tests and supplementary analyses

\begin{tabular}{|c|c|c|c|c|c|}
\hline & (12) Tobit & $\begin{array}{l}\text { (13) Negative } \\
\text { binomial }\end{array}$ & $\begin{array}{l}\text { (14) } \\
\text { Unpacking } \\
\text { philanthropy }\end{array}$ & $\begin{array}{l}\text { (15) H1: } \\
\text { SOX }\end{array}$ & $\begin{array}{l}\text { (16) H2: } \\
\text { SOX }\end{array}$ \\
\hline & $\begin{array}{l}\text { DV: } \text { CEO } \\
\text { overcomp }_{(t+1)}\end{array}$ & $\begin{array}{l}\text { DV: count } \\
\text { disapproval }\end{array}$ & $\begin{array}{l}\text { DV: } \\
\text { disapproval }\end{array}$ & $\begin{array}{l}\text { DV: } \\
\text { disapproval }\end{array}$ & $\begin{array}{l}\text { DV: } \mathrm{CEO} \\
\operatorname{overcomp}_{(\mathrm{t}+1)}\end{array}$ \\
\hline Overcomp. $*$ disapproval $*$ philanthropy & $\begin{array}{l}-0.24 * * \\
(0.09)\end{array}$ & & & & $\begin{array}{l}-0.25 * \\
(0.11)\end{array}$ \\
\hline Two-way interaction effects & Incl. & & & & \\
\hline CEO overcompensation & $\begin{array}{l}-0.19 \\
(0.15)\end{array}$ & $\begin{array}{l}0.38^{* * *} \\
(0.08)\end{array}$ & $\begin{array}{l}0.45 \\
(0.36)\end{array}$ & $\begin{array}{l}1.26^{* * *} \\
(0.22)\end{array}$ & $\begin{array}{l}0.13^{*} \\
(0.06)\end{array}$ \\
\hline Media disapproval & $\begin{array}{l}0.04 \\
(0.07)\end{array}$ & & & & $\begin{array}{l}-0.25^{*} \\
(0.11)\end{array}$ \\
\hline Philanthropy & $\begin{array}{l}0.15^{* * *} \\
(0.04)\end{array}$ & $\begin{array}{l}-1.02^{* * *} \\
(0.06)\end{array}$ & & $\begin{array}{l}-0.69 * * * \\
(0.12)\end{array}$ & $\begin{array}{l}-0.05 \\
(0.06)\end{array}$ \\
\hline Charitable giving & & & $\begin{array}{l}-0.57 * * * \\
(0.13)\end{array}$ & & \\
\hline Other "philanthropy” (e.g., in-kind) & & & $\begin{array}{l}-0.02 \\
(0.15)\end{array}$ & & \\
\hline Philanthropy $*$ CEO overcompensation & & $\begin{array}{l}0.72 * * * \\
(0.05)\end{array}$ & & $\begin{array}{l}1.53 * * * \\
(0.18)\end{array}$ & \\
\hline Charitable giving $*$ CEO overcomp. & & & $\begin{array}{l}0.61 * * \\
(0.19)\end{array}$ & & \\
\hline "Other philanthropy" * CEO overcomp. & & & $\begin{array}{l}0.74 * * * \\
(0.19)\end{array}$ & & \\
\hline Anticipated CEO compensation & $\begin{array}{l}-0.05 \\
(0.04)\end{array}$ & $\begin{array}{l}-0.10 \\
(0.10)\end{array}$ & $\begin{array}{l}0.13 \\
(0.15)\end{array}$ & $\begin{array}{l}0.14 \\
(0.13)\end{array}$ & $\begin{array}{l}-0.01 \\
(0.10)\end{array}$ \\
\hline Firm size & $\begin{array}{l}0.05^{* *} \\
(0.02)\end{array}$ & $\begin{array}{l}0.20^{* * *} \\
(0.04)\end{array}$ & $\begin{array}{l}0.17 * * \\
(0.06)\end{array}$ & $\begin{array}{l}0.20 * * * \\
(0.06)\end{array}$ & $\begin{array}{l}0.27 * * * \\
(0.05)\end{array}$ \\
\hline Firm age & $\begin{array}{l}-0.16^{* * *} \\
(0.02)\end{array}$ & $\begin{array}{l}-0.03 \\
(0.16)\end{array}$ & $\begin{array}{l}0.12 \\
(0.10)\end{array}$ & $\begin{array}{l}0.12 \\
(0.10)\end{array}$ & $\begin{array}{l}-1.32^{* * *} \\
(0.33)\end{array}$ \\
\hline Fortune most admired & $\begin{array}{l}-0.05^{*} \\
(0.02)\end{array}$ & $\begin{array}{l}-0.17 \\
(0.09)\end{array}$ & $\begin{array}{l}-0.09 \\
(0.11)\end{array}$ & $\begin{array}{l}-0.11 \\
(0.10)\end{array}$ & $\begin{array}{l}-0.04 \\
(0.03)\end{array}$ \\
\hline Media visibility & $\begin{array}{l}-0.02+ \\
(0.01)\end{array}$ & $\begin{array}{l}0.08^{* *} \\
(0.03)\end{array}$ & $\begin{array}{l}0.06^{*} \\
(0.03)\end{array}$ & $\begin{array}{l}0.06^{*} \\
(0.03)\end{array}$ & $\begin{array}{l}0.00 \\
(0.02)\end{array}$ \\
\hline Concerns "philanthropy” & $\begin{array}{l}-0.06^{*} \\
(0.03)\end{array}$ & $\begin{array}{l}-0.23^{*} \\
(0.09)\end{array}$ & $\begin{array}{l}0.03 \\
(0.11)\end{array}$ & $\begin{array}{l}0.01 \\
(0.11)\end{array}$ & $\begin{array}{l}0.02 \\
(0.04)\end{array}$ \\
\hline Shareholder return & $\begin{array}{l}0.10^{* *} \\
(0.04)\end{array}$ & $\begin{array}{l}-0.21 * * \\
(0.07)\end{array}$ & $\begin{array}{l}-0.21 * \\
(0.10)\end{array}$ & $\begin{array}{l}-0.20^{*} \\
(0.10)\end{array}$ & $\begin{array}{l}-0.02 \\
(0.04)\end{array}$ \\
\hline Return on assets & $\begin{array}{l}0.67 * * * \\
(0.10)\end{array}$ & $\begin{array}{l}-1.17 * * \\
(0.44)\end{array}$ & $\begin{array}{l}0.12 \\
(0.53)\end{array}$ & $\begin{array}{l}0.09 \\
(0.51)\end{array}$ & $\begin{array}{l}0.71 * * \\
(0.25)\end{array}$ \\
\hline CEO/Chairman duality & $\begin{array}{l}0.09 * * * \\
(0.02)\end{array}$ & $\begin{array}{l}0.03 \\
(0.09)\end{array}$ & $\begin{array}{l}-0.07 \\
(0.08)\end{array}$ & $\begin{array}{l}-0.07 \\
(0.08)\end{array}$ & $\begin{array}{l}0.03 \\
(0.04)\end{array}$ \\
\hline CEO tenure & $\begin{array}{l}0.01 \\
(0.01)\end{array}$ & $\begin{array}{l}0.13^{* *} \\
(0.04)\end{array}$ & $\begin{array}{l}0.10^{*} \\
(0.04)\end{array}$ & $\begin{array}{l}0.08 \\
(0.04)\end{array}$ & $\begin{array}{l}0.01 \\
(0.02)\end{array}$ \\
\hline
\end{tabular}




\begin{tabular}{l|lllll} 
Founder CEO & $-0.16^{*}$ & -0.43 & -0.12 & -0.09 & -0.17 \\
Female CEO & $(0.08)$ & $(0.26)$ & $(0.19)$ & $(0.19)$ & $(0.20)$ \\
& -0.03 & 0.33 & -0.41 & -0.44 & 0.03 \\
Shareholder activism & $(0.15)$ & $(0.31)$ & $(0.28)$ & $(0.25)$ & $(0.12)$ \\
Number of analysts following & $-0.14^{* * *}$ & $0.13^{*}$ & 0.08 & 0.11 & -0.03 \\
& $(0.04)$ & $(0.06)$ & $(0.07)$ & $(0.07)$ & $(0.05)$ \\
Post Sarbanes-Oxley (=1) & & -0.04 & 0.13 & 0.10 & \\
& & $(0.07)$ & $(0.08)$ & $(0.07)$ & \\
Inverse Mills ratio & & & & $\mathbf{- 0 . 0 6}$ & $\mathbf{0 . 1 0 * *}$ \\
Constant & & & & $\mathbf{( 0 . 1 3 )}$ & $\mathbf{( 0 . 0 4 )}$ \\
& $-0.56^{* * *}$ & $1.43^{* * *}$ & $1.69^{*}$ & $1.94 * * *$ & 0.07 \\
\hline Year dummies & $(0.11)$ & $(0.23)$ & $(0.84)$ & $(0.55)$ & $(0.15)$ \\
Industry dummies & $1.82^{* * *}$ & $-3.48^{* * *}$ & $-7.48^{* * *}$ & $-8.06^{* * *}$ & $2.44^{* *}$ \\
Firm fixed-effects & $(0.48)$ & $(1.05)$ & $(1.59)$ & $(1.19)$ & $(0.91)$ \\
Number of observations & Incl. & Incl. & Incl. & Incl. & Incl. \\
Adjusted R-Squared (Wald Chi2) & Incl. & & Incl. & Incl. & \\
\hline
\end{tabular}

Note. Standard errors are shown in parentheses. ${ }^{*} p<0.05,{ }^{* *} p<0.01,{ }^{* * *} p<0.001$

\section{REFERENCES}

Adut A (2005) A theory of scandal: Victorians, homosexuality, and the fall of Oscar Wilde. American Journal of Sociology 111: $213-248$.

Aguilera RV, Desender K, Bednar MK, Lee J (2015) Connecting the dots: Bringing external corporate governance into the corporate governance puzzle. Academy of Management Annals 9(1): 483-573.

Aguilera RV, Rupp DE, Williams CA, Ganapathi J (2007) Putting the S Back in Corporate Social Responsibility: A Multilevel Theory of Social Change in Organizations. Academy of Management Review 32(3): 836-863.

Bansal P, Clelland I (2004) Talking trash: legitimacy, impression management, and unsystematic risk in the context of the natural environment. Academy of Management Journal 47(1): 93-103.

Bascle G (2008) Controlling for endogeneity with instrumental variables in strategic management research. Strategic Organization, 6(3), 285-327.

Bednar MK (2012) Watchdog or lapdog? A behavioral view of the media as a corporate governance mechanism. Academy of Management Journal 55(1): 131-150.

Bednar MK, Boivie S, Prince NR (2013) Burr under the saddle: How media coverage influences strategic change. Organization Science 24(3): 910-925.

Bishop M, Lemann N, Lublin J, Useem J. The Media and Executive Compensation: A Panel Discussion (December 2005). Available at SSRN: http://ssrn.com/abstract $=869811$

Bogle, J. C (2008) Reflections on CEO compensation. Academy of Management Perspectives 22: 21-25.

Brookman J, Jandik T, Rennie C (2006) A comparison of CEO compensation data sources. Financial Management Association Annual Meeting. Consulted online on Feb 4, 2018 at www.researchgate.net/profile/Craig_Rennie 
Carberry E, Zajac E (2017) How U.S. Corporations Changed Executive Compensation after Enron: Symbol and Substance. Academy of Management Proceedings, 15134

Certo ST, Busenbark J, Woo HS, Semadeni M (2016). Sample selection bias and Heckman models in strategic management research. Strategic Management Journal 37, 2639-2657.

Cheng IH, Hong H., Shue K (2015) Do managers do good with other peoples' money? Working Paper. Tuck School, Dartmouth.

Cohen T (2011) Debt crisis at crossroads for non-profits. Philanthropy Journal 1: 1

Core J, Guay W, Larcker D (2008) The power of the pen and executive compensation. Journal of Financial Economics 88(1): 1-25.

Crilly D, Zollo M, Hansen M (2012) Faking it or muddling through? Understanding decoupling in response to stakeholder pressures. Academy of Management Journal 55(6): 1429-1449.

Crilly D, Hansen M, Zollo M (2016) The grammar of decoupling: A cognitive-linguistic perspective on firms' sustainability claims and stakeholders' interpretation. Academy of Management Journal 59(2): 705-729.

Crystal G (1991) In Search of Excess (New York: Norton)

Dahl MS, Dezső CL, Ross DG (2012) Fatherhood and managerial style: How a male CEO's children affect the wages of his employees. Administrative Science Quarterly 57(4): 669-693.

Dawson JF, Richter AW (2006) Probing three-way interactions in moderated multiple regression: Development and application of a slope difference test. Journal of Applied Psychology 91(4): 917-926.

Deephouse D (2000) Media reputation as a strategic resource: an integration of mass communication and resource-based theories. Journal of Management 26: 1091-1112.

Deephouse D, Heugens P (2009) Linking social issues to organizational impact: the role of infomediaries and the infomediary process. Journal of Business Ethics 86: 541-553.

Deephouse D, Suchman M (2008) Legitimacy in organizational institutionalism. In The SAGE Handbook of Organizational Institutionalism, Greenwood R, Oliver C, Sahlin K, Suddaby R (eds). Sage: Thousand Oaks, CA; 49-77.

Deutsch C. H (2008) Executive pay: A special report; a brighter spotlight, yet the pay rises. New York Times, April 6.

Di Giuli A, Kostovetsky L (2014) Are red or blue companies more likely to go green? Politics and corporate social responsibility. Journal of Financial Economics 111(1): 158-180.

Durand R. and Vergne J.-P (2015) Asset divestment as a response to media attacks in stigmatized industries. Strategic Management Journal 36(8): 1205-23

Dyck A., Zingales L. (2002) The corporate governance role of the media. Unpublished working paper. Harvard University.

Dyck A, Volchkova N, Zingales L (2008) The corporate governance role of the media: Evidence from Russia. Journal of Finance 63(3): 1093-1135.

Edelman LB (1992) Legal ambiguity and symbolic structures: organizational mediation of civil rights law. American Journal of Sociology 97(6): 1531-1576.

Elsbach K, Kramer R (1996) Members' responses to organizational identity threats: encountering and countering the Business Week rankings. Administrative Science Quarterly 41: 442-476.

Flammer C (2015) Does Corporate Social Responsibility Lead to Superior Financial Performance? A Regression Discontinuity Approach. Management Science 61(11): 2549-2568 
Fiske ST, Neuberg SL, Beattie AE, Milberg SJ (1987) Category-based and attribute-based reactions to others: some informational conditions of stereotyping and individuating process. Journal of Experimental Social Psychology 23: 399-427

Fong E, Misangyi V, Tosi H (2010) The effect of CEO pay deviations on CEO withdrawal, firm size, and firm performance. Strategic Management Journal 31(6): 629-651.

Gautier A, Pache A (2015) Research on corporate philanthropy : A review and assessment. Journal of Business Ethics 126(3): 343-69.

Godfrey, PC (2005) The relationship between corporate philanthropy and shareholder wealth: A risk management perspective.

Academy of Management Review 30: 777-798.

Godfrey PC, Merrill CB, Hansen JM (2009) The relationship between corporate social responsibility and shareholder value: an empirical test of the risk management hypothesis. Strategic Management Journal 30(4): 425-445.

Graves SB, Waddock SA (1994) Institutional owners and corporate social performance. Academy of Management Journal 37: $1034-1046$.

Gurun, UG (2016) Benefits of Publicity. Unpublished working paper. University of Texas at Dallas.

Hsieh YY, Vergne JP, Wang S (2018) The internal and external governance of blockchain-based organizations: Evidence from cryptocurrencies, in Campbell-Verduyn M (ed.), Bitcoin and Beyond: Blockchains and Global Governance: 48-68. RIPE/Routledge Series in Global Political Economy

Hsu G, Hansen MT, Kocak O (2009) Multiple category memberships in markets: An integrative theory and two empirical tests.

American Sociological Review 74(1): 150-169.

Institute for Policy Research (2013) Following the public on inequality. www.ipr.northwestern.edu/about/news/2013/mccallundeserving-rich.html, Accessed 10 June 2015

Jensen M (2006) Should we stay or should we go? Accountability, status anxiety, and client defection. Administrative Science Quarterly 51: 97-128.

Joe JR., Louis H, Robinson D (2009) Managers' and investors' responses to media exposure of board ineffectiveness, Journal of Financial and Quantitative Analysis 44(3): 579-605.

Jonsson S, Greve H, Fujiwara-Greve T (2009) Undeserved loss: the spread of legitimacy loss to innocent organizations in response to reported corporate deviance. Administrative Science Quarterly 54: 195-228.

Joseph J, Ocasio W, McDonnell M (2014) The structural elaboration of board independence: Executive power, institutional logics, and the adoption of CEO-only board structures in U.S. corporate governance. Academy of Management Journal 57(6): $1834-1858$.

Kacperczyk A (2009) With greater power comes greater responsibility? Takeover protection and corporate attention to stakeholders. Strategic Management Journal 30(3): 261-285.

Kay I, Van Putten S (2008) Executive Pay: Regulation vs. Market Competition. Policy Analysis 619: 1-14

King B, McDonnell M-H (2015) Good firms, good targets: The relationship between corporate social responsibility, reputation, and activist targeting. In Corporate Social Responsibility in a Globalizing World, Tsutsui K, Lim A (eds.), Cambridge University Press: $430-455$.

Kolev K., Wiseman RM and Gomez-Mejia LR (2017) Do CEOs ever lose? Fairness perspective on the allocation of residuals between CEOs and shareholders. Journal of Management 43(2): 610-637

Kuhnen CM, Niessen-Rünzi A (2012) Public opinion and executive compensation. Management Science 58(7): 1249-1272.

Lange D, Washburn N (2012) Understanding Attributions of Corporate Social Irresponsibility. Academy of Management Review, 37(2), 300-326.

Lerner M, Miller D (1978) Just world research and the attribution process: Looking back and ahead. Psychological Bulletin 85: $1030-51$. 
Madsen P, Rodgers Z (2015) Looking good by doing good: The antecedents and consequences of stakeholder attention to corporate disaster relief. Strategic Management Journal 36(5): 776-794

Margolis J, Elfenbein H, Walsh JP (2007) Does it pay to be good? A meta-analysis and redirection of research on the relationship between corporate social and financial performance, Working Paper: Ross School of Business, University of Michigan.

Marquis C, Lounsbury M (2007) Vive la résistance: Competing logics and the consolidation of US community banking. Academy of Management Journal 50(4): 799-820.

Mattingly JE, Berman SL (2006) Measurement of corporate social action: discovering taxonomy in the Kinder Lydenberg Domini ratings data. Business \& Society 45(1): 20-46.

McCall L (2013) The Undeserving Rich: American Beliefs about Inequality, Opportunity, and Redistribution. Cambridge University Press

Milgrom P, Roberts J (1986) Price and advertising signals of product quality. Journal of Political Economy 94: 796-821.

Mishina Y, Block E, Mannor M. (2012) The path dependence of organizational reputation: how social judgment influences assessments of capability and character. Strategic Management Journal 33: 459-477.

Muller A, Kräussl R (2011) Doing good deeds in times of need: A strategic perspective on corporate disaster donations. Strategic Management Journal 32: 911-929.

Muller A, Pfarrer M, Little L (2014) A theory of collective empathy in corporate philanthropy decisions. Academy of Management Review, 39(1): 1-21.

Nigam A, Ocasio W (2010) Event attention, environmental sense- making, and change in institutional logics: An inductive analysis of the effects of public attention to Clinton's health care reform initiative. Organization Science 21(4) 823-841.

Orlitzky M (2013) Corporate social responsibility, noise, and stock market volatility. Academy of Management Perspectives 27(3): $238-254$.

Pache A, Santos F (2010) When worlds collide: The internal dynamics of organizational responses to conflicting institutional demands. Academy of Management Review 35(3), 455-476.

Palia D (2001) The Endogeneity of Managerial Compensation in Firm Valuation: A Solution. Review of Financial Studies 14(3): 735-764.

Papke L, Wooldridge J (1996) Econometric methods for fractional response variables with an application to 401(k) plan participation rates. Journal of Applied Econometrics 11: 619-632.

Park HD, Steensma HK (2012) When does corporate venture capital add value for new ventures? Strategic Management Journal 33: 1-22.

Pfarrer M, Decelles K, Smith K, Taylor M (2008) After the fall: Reintegrating the corrupt organization. Academy of Management Review, 33(3): 730-749.

Pfarrer MD, Pollock TG, Rindova VP (2010) A tale of two assets: the effects of firm reputation and celebrity on earnings surprises and investors' reactions. Academy of Management Journal 53(5): 1131-1152.

Pollock TG, Rindova VP (2003) Media legitimation effects in the market for initial public offerings. Academy of Management Journal 46(5): 631-642.

Rao H, Yue L, Ingram P (2010) Activists, categories, and markets: Racial diversity and protests against Walmart store openings in America, in Hsu G, Negro G, Koçak O (eds.), Categories in Markets: Origins and Evolution, Emerald Publishing: 235 - 253

Rhee M, Haunschild P (2006) The liability of good reputation: A study of product recalls in the US automobile industry. Organization Science, 17(1): 101-117.

Rutherford M, Buchholtz A, Brown JA (2007) Examining Relationships Between Monitoring and Incentives in Corporate Governance. Journal of Management Studies 44(3): 414-430. 
Short JC, McKenny AF, Ketchen DJ, Snow CC, Hult GTM (2016) An empirical examination of firm, industry, and temporal effects on corporate social performance. Business \& Society 55(8): 1122-1156.

Sine W, David R, Mitsuhashi H (2007) From Plan to Plant: Effects of Certification on Operational Start-up in the Emergent Independent Power Sector. Organization Science, 18(4), 578-594.

Skowronski JJ, Carlston DE (1989) Negativity and extremity biases in impression formation: a review of explanations. Psychological Bulletin 105(1): 131-142.

Spence M (1973) Job market signaling. The Quarterly Journal of Economics 87(3): 355-374.

Spence M (2002) Signaling in retrospect and the informational structure of markets. American Economic Review 92(3): 434-459.

Stern I, Dukerich J, Zajac E (2014) Unmixed signals: how reputation and status affect alliance formation. Strategic Management Journal 35(4): 512-531.

Su W, Sauerwald S (2015) Does corporate philanthropy increase firm value? The moderating role of corporate governance. Business \& Society, forthcoming

Sullivan B, Haunschild P, Page K (2007) Organizations non gratae? The impact of unethical corporate acts on interorganizational networks. Organization Science 18: 55-70.

Thornton PH, Ocasio W, Lounsbury M (2015) The institutional logics perspective, In Emerging Trends in the Social and Behavioral Sciences: An Interdisciplinary, Searchable, and Linkable Resource. Scott R, Kosslyn S. (eds). Wiley: 1-22.

Takacs Haynes K, Campbell JT, Hitt MA (2015) When More Is Not Enough: Executive Greed and Its Influence on Shareholder Wealth. Journal of Management, forthcoming doi:10.1177/0149206314535444

Vergne JP (2011) Toward a New Measure of Organizational Legitimacy: Method, Validation, and Illustration. Organizational Research Methods, 14(3), 484-502.

Vergne JP (2012) Stigmatized categories and public disapproval of organizations: a mixed-methods study of the global arms industry, 1996-2007. Academy of Management Journal 55(5): 1027-1052.

Vergne JP, Wry T (2014) Categorizing categorization research: Review, integration, and future directions. Journal of Management Studies 51(1): 56-94.

Wade JB, O'Reilly CA, Pollock TG (2006) Overpaid CEOs and underpaid managers: fairness and executive compensation. Organization Science 17:527-44

Waddock S (2003) Myths and realities of social investing. Organization \& Environment 16(3): 369-380.

Walsh J, Seward J (1990) On the efficiency of internal and external corporate control mechanisms. Academy of Management Review 15(3): 421-458.

Wang H, Qian C (2011) Corporate philanthropy and corporate financial performance: the roles of stakeholder response and political access. Academy of Management Journal 54(6): 1159-1181.

Watts, D. J., \& Rothschild, D. 2017. Rebuilding legitimacy in a post-truth age. https://medium.com/@,duncanjwatts/rebuildinglegitimacy-in-a-post-truth-age-2f9af19855a5\#.xjllnrfku. Accessed January 20, 2017.

Weber K, Rao H, Thomas LG (2009) From streets to suites: How the anti-biotech movement affected German pharmaceutical firms. American Sociological Review 74(1): 106-127.

Westphal J, Deephouse D (2011) Avoiding bad press: Interpersonal influence in relations between CEOs and journalists and the consequences for press reporting about firms and their leadership. Organization Science 22(4): 1061-1086. 
Westphal J, Park S, McDonald M, Hayward M (2012) Helping Other CEOs Avoid Bad Press Social Exchange and Impression Management Support among CEOs in Communications with Journalists. Administrative Science Quarterly 57(2): 217-268

Williams RJ, Barrett JD (2000) Corporate philanthropy, criminal activity, and firm reputation: is there a link? Journal of Business Ethics 26: $341-350$.

Wooldridge JM (2010) Econometric Analysis of Cross Section and Panel Data. MIT Press: Cambridge, MA.

Wowak AJ, Hambrick DC, Henderson AD (2011) Do CEOs encounter within-tenure settling up? A multiperiod perspective on executive pay and dismissal. Academy of Management Journal 54(4): 719-739.

Younge KA, Tong TW, Fleming L (2015) How anticipated employee mobility affects acquisition likelihood: evidence from a natural experiment. Strategic Management Journal 36(5): 686-708.

Zajac EJ, Westphal JD (1994) The Costs and Benefits of Managerial Incentives and Monitoring in Large U.S. Corporations: When is More not Better? Strategic Management Journal 15(S1): 121-142.

Zavyalova A, Pfarrer M, Reger R, Shapiro D (2012) Managing the message: the effects of firm actions and industry spillovers on media coverage following wrongdoing. Academy of Management Journal 55(5): 1079-1101.

Zavyalova A, Pfarrer M, Reger R, Hubbard T (2016) Reputation as a benefit and a burden? How stakeholders' organizational identification affects the role of reputation following a negative event. Academy of Management Journal 59(1): 253-276.

Zuckerman E (1999) The categorical imperative: securities analysts and the illegitimacy discount. American Journal of Sociology 104(5): 1398-1438.

\section{APPENDIX A}

Over our period of study, the terms most associated with "corporate philanthropy" in Factiva included "generosity", "virtue", and "charitable". By contrast, the keywords associated with "CEO overcompensation" included "fat cat" and "wrongful". Besides, a generic search on "selfish" or "greedy" returned "executive compensation" as a related term, meaning that the association runs both ways - the media relate CEO overcompensation to greed (e.g., "fat cat"), but also relate greedy/selfish behavior to CEO compensation. Similarly, altruism and generosity were related to "charitable donations", thereby providing further evidence of the perceived association between philanthropy and altruism/generosity. Furthermore, "altruism" is commonly listed by dictionaries as an antonym for both "selfishness" and "greed" - and the latter is listed as an antonym for "generosity". For Factiva searches, we used search queries such as: "[(greedy or selfish) near20 (corporat* or firm* or company or companies or conglomerate* or CEO* or executive* $\left.^{*}\right)$, and a similar one with (altruis* or genero*)".

We are not implying that philanthropy is only associated with altruism and generosity. Like any signal, it is subject to interpretation, and this is also true of CEO overcompensation. For the purpose of this study, all we need are two signals that are often (not always) associated with contradicting values from the viewpoint of one specific audience-here, the media. We simply observe that, on average, the media relate overcompensation to greed/selfishness (compared to firms that do not overcompensate CEOs) and philanthropy to altruism/generosity (compared to firms that never engage in philanthropy). The coefficient on CEO overcompensation in Model 4, Table 2 provides additional support to the idea that CEO overcompensation and philanthropy are at odds.

\section{APPENDIX B}

Table 2's Models 5 and 6, using only 2001-2006 observations $(n=6,033$ instead of 8,004)

\begin{tabular}{lll}
\hline & $\begin{array}{l}(5) \\
\text { Baseline H Disapproval } \\
\text { (GLM) }\end{array}$ & $\begin{array}{l}(6) \\
\text { H1 test Disapproval } \\
\text { (GLM) }\end{array}$ \\
\hline Corporate philanthropy X CEO overcompensation & & $1.47^{* * *}$ \\
CEO overcompensation & & $(0.19)$ \\
& $0.81 *$ & $1.03^{* * *}$
\end{tabular}




\begin{tabular}{|c|c|c|}
\hline & $(0.43)$ & $(0.21)$ \\
\hline \multirow[t]{2}{*}{ Corporate philanthropy } & $-0.43 * * *$ & $-0.73 * * *$ \\
\hline & $(0.10)$ & $(0.13)$ \\
\hline \multirow[t]{2}{*}{ Anticipated CEO compensation } & 0.07 & 0.17 \\
\hline & $(0.17)$ & $(0.15)$ \\
\hline \multirow[t]{2}{*}{ Firm size } & $0.30 * * *$ & $0.27 * * *$ \\
\hline & $(0.08)$ & $(0.06)$ \\
\hline \multirow[t]{2}{*}{ Firm age } & 0.16 & $0.20+$ \\
\hline & $(0.10)$ & $(0.10)$ \\
\hline \multirow[t]{2}{*}{ Fortune most admired } & -0.12 & -0.15 \\
\hline & $(0.12)$ & $(0.11)$ \\
\hline \multirow[t]{2}{*}{ Media visibility } & $0.06+$ & $0.06^{*}$ \\
\hline & $(0.03)$ & $(0.03)$ \\
\hline \multirow[t]{2}{*}{ Concerns corporate philanthropy } & -0.03 & -0.10 \\
\hline & $(0.14)$ & $(0.13)$ \\
\hline \multirow[t]{2}{*}{ Shareholder return } & $-0.31 *$ & $-0.30 * *$ \\
\hline & $(0.12)$ & $(0.11)$ \\
\hline \multirow[t]{2}{*}{ Return on Assets } & 0.57 & 0.55 \\
\hline & $(0.63)$ & $(0.55)$ \\
\hline \multirow[t]{2}{*}{ CEO/Chairman duality } & $-0.15+$ & $-0.17+$ \\
\hline & $(0.09)$ & $(0.09)$ \\
\hline \multirow[t]{2}{*}{ CEO Tenure } & 0.09 & 0.07 \\
\hline & $(0.06)$ & $(0.05)$ \\
\hline \multirow[t]{2}{*}{ Founder CEO } & 0.09 & 0.16 \\
\hline & $(0.20)$ & $(0.20)$ \\
\hline \multirow[t]{2}{*}{ Female CEO } & $-0.89 * * *$ & $-0.95^{* * *}$ \\
\hline & $(0.27)$ & $(0.23)$ \\
\hline \multirow[t]{2}{*}{ Shareholder activism } & 0.11 & 0.08 \\
\hline & $(0.10)$ & $(0.09)$ \\
\hline \multirow[t]{2}{*}{ Number of analysts following } & 0.10 & 0.03 \\
\hline & $(0.09)$ & $(0.07)$ \\
\hline \multirow[t]{2}{*}{ Inverse Mills ratio } & $1.96+$ & $2.68^{* * *}$ \\
\hline & $(1.02)$ & $(0.44)$ \\
\hline \multirow[t]{2}{*}{ Constant } & $-8.46^{* * *}$ & $-9.54 * * *$ \\
\hline & $(1.98)$ & $(1.15)$ \\
\hline Year \& Industry dummies & Incl. & Incl. \\
\hline
\end{tabular}

\section{APPENDIX C}

We used the following search string to locate articles in Factiva: (CEO NAME or CEO NAME'S) near20 (compensation or salary or bonus or option* near10 grant or option* near10 receiv* or option* near10 exercis* or restricted stock or (pay near 500 ) or (was paid near 500 ) or (pay near 5 million*) or (was paid near 5 million*)) and (CEO NAME or CEO NAME'S) same (compensation or salary or bonus or option* near10 grant or option* near10 receiv* or option* near10 exercis* or restricted stock or (pay near5 00) or (was paid near5 00) or (pay near5 million*) or (was paid near5 million*)) and ((CEO NAME or CEO NAME'S) same (FIRM NAME or FIRM NAME'S)). 


\section{APPENDIX D}

String used to code articles as negative-toned:

(CEO name or CEO names or executive* or CEO*) near25 (high* near7 (salar* or bonus* or pay* or paid or compensat* or benefit*) or excess* near7 (salar* or bonus* or pay* or paid or compensat* or benefit* or option*) or lofty near7 (salar* or bonus* or pay* or paid or compensat* or benefit* or option*) or hefty near7 (salar* or bonus* or pay* or paid or compensat* or benefit* or option*) or large near7 (salar* or bonus* or pay* or paid or compensat* or benefit* or option*) or rich near7 (salar* or bonus* or pay* or paid or compensat* or benefit* or option*) or big* near7 (salar* or bonus* or pay* or paid or compensat* or benefit* or option*) or outsize* near7 (salar* or bonus* or pay* or paid or compensat* or benefit* or option*) or score* near7 (salar* or bonus* or pay* or paid or compensat* or benefit* or option*) or huge near7 (salar* or bonus* or pay* or paid or compensat* or benefit* or option*) or generous near7 (salar* or bonus* or pay* or paid or compensat* or benefit* or option*) or exorbitant* near7 (salar* or bonus* or pay* or paid or compensat* or benefit* or option*) or fat* near7 (salar* or bonus* or pay* or paid or compensat* or benefit* or option*) or gargantuan near7 (salar* or bonus* or pay* or paid or compensat* or benefit* or option*) or bonanza* near7 (salar* or bonus* or pay* or paid or compensat* or benefit* or option*) or jumbo near7 (salar* or bonus* or pay* or paid or compensat* or benefit* or option*) or whopp* near7 (salar* or bonus* or pay* or paid or compensat* or benefit* or op- tion*) or astound* near7 (salar* or bonus* or pay* or paid or compensat* or benefit* or option*) or ridiculous* near7 (salar* or bonus* or pay* or paid or compensat* or benefit* or option*) or stagger* near7 (salar* or bonus* or pay* or paid or compensat* or benefit* or option*) or hand- some* near7 (salar* or bonus* or pay* or paid or compensat* or benefit* or option*) or lucrative near7 (pay* or compensat* or option*) or critic* near7 (pay* or compensat*) or best near7 paid or reap* adj7 million* or self-serving or largesse or overpaid or lavish or perks or perquisites or windfall* or earn* more than or was paid more than or receiv* more than or made more than)

\section{APPENDIX E}

We operationalized CEO overcompensation as the difference between anticipated and observed pay using the whole ExecuComp database as the sample (II). Observed compensation was total CEO compensation as reported in ExecuComp (variable TDC1). Anticipated compensation was computed as follows (I):

I. $\quad \log (\text { Anticipated Total Compensation })_{i t}=a+x_{i t} \beta+u_{i t}$, where $\mathrm{x}_{\mathrm{it}}$ included $\log ($ Firm Sales (t-1)), dummy for SP500 membership, $\log (\mathrm{CEO}$ Tenure), Shareholder Return, Shareholder Return ( $\mathrm{t}-1)$, Return on Assets, Return on Assets ( $\mathrm{t}-1)$, and dummies based on two digit SIC codes.

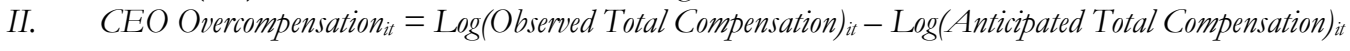

Regression results mirror those of earlier studies in terms of coefficients, significance, and $\mathrm{R}^{2}$.

\section{APPENDIX F}

We use two-stage models to test our hypotheses because: $1 /$ there may be systematic differences between firms that engage in philanthropy and firms that do not, between firms that overcompensate their CEOs and firms that do not, or between firms targeted by the media and firms that are not. These differences could be driven by the existence of omitted variables that we cannot observe (e.g., top managers' exceptional communication skills could explain the lack of media disapproval and be correlated with executive pay); and 2/ we can only observe the effect of signal incongruence on media disapproval when both philanthropy and CEO overcompensation are present, and we can only observe the longer-term decrease in CEO overcompensation when both philanthropy and media disapproval are present. Thus, there is potentially sample selection in our data. As noted by Certo et al. (2016: 2642), "sample selection involves incidental truncation. Incidental truncation occurs when the dependent variable is 'observed only if other variables take on particular values' (Wooldridge, 2010: 777)". To address this potential issue, we estimate all our models using the twostep Heckman procedure (reported in Table 2) with "exclusion restrictions", which act as instrumental variables in the first-stage (selection) equations (e.g., Park and Steensma 2012), and do not appear in the second-stage models. The firststage models isolate exogenous variation in the main predictors so they can be safely included in the second-stage model, net of a correction term called "Inverse Mills ratio" (Bascle 2008).

To test the baseline and signal incongruence (H1) hypotheses, we first estimate a selection equation to recognize that systematic differences may exist between firms that overcompensate their $\mathrm{CEO}$ and firms that do not. We use five exclusion restrictions to predict the presence of overcompensation: $1 /$ the mean level of CEO

overcompensation in $\mathrm{t}-1$ in the focal firm's industry; 2/ whether the CEO has an elite educational background (1) or not (0). We coded this variable as in Palia's (2001: 745) study on the endogeneity of executive compensation after manually 
collecting data for each CEO in Marquis Who is Who, firms' annual reports, the NNDB database, LinkedIn, and Wikipedia. For instance, if the CEO graduated from law school, the variable is coded 1 for the following schools: Berkeley, Chicago, Columbia, Harvard, Michigan, NYU, Pennsylvania, Stanford, and Yale. Similar coding rules apply for undergraduate degrees, engineering degrees, and MBA degrees; 3 / the volatility of the share price, also coded as suggested by Palia (2001) using CRSP data; 4/ the number of children a CEO has, and 5/ the number of boys among a CEO's children. Indeed Dahl et al. (2012: 669) found that "male CEOs pay themselves more after fathering a child, especially after fathering a son". Child gender is the outcome of a random process and is unlikely to affect media disapproval. We got information on CEOs' offspring by manually searching each CEO's name in Marquis Who is Who, NNDB, Wikipedia, in public corporate filings (e.g., a firm would sometimes state that a CEO holds a certain number of shares on behalf of her or his children), and in CEO biographies and obituaries (e.g. CEO X was survived by daughter Y and son Z). Empirically, we find all five exclusion restrictions to be significant predictors of CEO overcompensation unrelated to media disapproval (see model 1 in Table 2).

To test our signal incongruence hypothesis (H1), which involves an interaction effect between CEO overcompensation and philanthropy, we also estimate a selection equation predicting which firms likely engage in philanthropy. We use two exclusion restrictions to predict philanthropy: 1 / the mean level of philanthropy in the industry in the previous period, after excluding the focal firm. Indeed it has been argued and showed empirically (Short et al. 2016) that industry membership affects engagement in prosocial activities, yet industry peers' philanthropy will not affect pay-related disapproval of the focal firm; and, 2/ the percentage of votes earned by the Democrats in the previous presidential elections in the U.S. state where the focal firm is headquartered. Indeed Di Giuli and Kostovetsky (2014) showed that firms based in Democrat-leaning states exhibit more prosocial activities, yet voting outcomes are unrelated to media disapproval. Empirically, we find both exclusion restrictions to be significant predictors of philanthropy unrelated to media disapproval (see model 4 in Table 2).

To test $\mathrm{H} 2$ predicting an overcompensation decrease in $\mathrm{t}+1$, we do two things. First, since media disapproval acts as a dependent variable in $\mathrm{H} 1$ and as a predictor in $\mathrm{H} 2$, we collected data to instrument it and test its effect on overcompensation in $\mathrm{t}+1$ after controlling for endogeneity. We create three instrumental variables to that end: $1 /$ the number of financial analysts following the firm in period t. Analysts are well connected to the media and often get interviewed by journalists, so a larger follower base will likely affect media coverage but will likely not affect the decision to decrease CEO overcompensation in $\mathrm{t}+1 ; 2$ / the number of "media directors" on the board of the focal firm. Media directors are board members who have worked or are currently employed as top executives, board members, editors or journalists at a media or publishing company. We assembled a list of all board members from the RiskMetrics and BoardEx databases, complemented by SEC filings, and manually searched each director's current and past employment at media or publishing firms. Gurun (2016) show that firms with media directors receive more media attention and more positive coverage, so our variable could capture, at least partly, the top managerial communication skills mentioned above. In our sample, 6 percent of firm-year observations have a media director, and 4.2 percent of directors are media directors; and 3 / the median distance between the location of a firm's headquarters (HQs) and the HQs of all media organizations that provided media data for this study in the Factiva database. Firms located closer to media organizations are more likely to be targeted in the press (Vergne 2011), but their proximity to media organizations' HQs should not affect CEO compensation levels. We got the location of firm HQs by searching through the SEC's public filings for HQ ZIP codes (on a yearly basis to capture changes in HQ location). We collected data on HQ location for media organizations from the descriptions of news sources in Factiva. We then collected data on longitude and latitude to compute the geodesic distance between each firm's HQ and each media organization's HQ, and used the median value of these distances to create the instrumental variable for each firm. As explained below, using these instruments we do find a negative and significant effect of media disapproval on CEO overcompensation in $\mathrm{t}+1$ (see model 7 in Table 3).

Second, we estimate a selection equation predicting which firms are targeted by the media to begin with (i.e., more than half are not). We use three exclusion restrictions in the selection equation (first stage) to predict media disapproval: $1 /$ the number of financial analysts following the firm in period $\mathrm{t}$; and $2 /$ the number of media directors on the board of the focal firm; and 3/ the median distance between a firm's and media organizations' HQs. All three exclusion restrictions significantly predict media disapproval and are unrelated to the decision to decrease CEO overcompensation in $\mathrm{t}+1$ (see model 8 in Table 3). These selection models address endogeneity in a different way and are more amenable to testing interaction effects involving media disapproval. 